\title{
Input-Output Analysis of the Interdependence Between Japan and China Through Japanese Overseas Production
}

\author{
Mitsuo Yamada
}

Received: 6 November 2013 / Accepted: 29 April 2014 / Published online: 9 June 2014 (C) 2014 M. Yamada; licensee Springer. This is an Open Access article distributed under the terms of the Creative Commons Attribution License (http://creativecommons.org/licenses/by/2.0), which permits unrestricted use, distribution, and reproduction in any medium, provided the original work is properly cited.

\begin{abstract}
We reconstructed the 2007 Japan-China International Input-Output Table as one that extracts Japanese production activities from China, using microdata of about 3,600 establishments in the METI Statistics "Survey of Overseas Business Activities." The recompiled input-output table consists of Japan, China (minus Japanese subsidiaries), and Japanese subsidiary activities in China with 30 sectors for each. Using this table, we discuss two topics. One is the regional contribution of value-added and imports against a one-unit increase of final demand in the Japanese subsidiary sector. The other is a simulation analysis of the production shift from Japan to China.
\end{abstract}

\section{Introduction}

The globalization of economies has prompted firms in developed countries to expand their plants and branches to foreign countries, and to supply their products to countries worldwide. Their motives would include a considered reduction of production costs, a strengthening of competitive advantages, and development of new markets. International relocation of production plans introduces segmentation and internationalization of the production process, in which international trade within firms or industries plays an important role.

Figure 1 shows foreign direct investment, FDI, of Japan after 1989 and regional shares of her overseas production in 2007 . Because the yen gradually appreciated in relation to the dollar in the latter half of the 1980s, Japanese firms started moving their plants and branches abroad to the US, Europe, and Asian countries, especially China.

On the other hand, the Chinese economy has been continuously growing after the introduction of market mechanisms into its own economy. FDI from abroad played

M. Yamada $(\bowtie)$

School of Economics, Chukyo University, 101-2 Yagoto Honmachi, Showa-ku, Nagoya, 466-8666, Japan

e-mail: yamada@mecl.chukyo-u.ac.jp 
Fig. 1 Data Source: Ministry of Finance, Foreign Direct Investment of Japan, Bank of Japan, Balance of Payment, and Ministry of Economy, Trade, and Industry, Overseas Business Survey

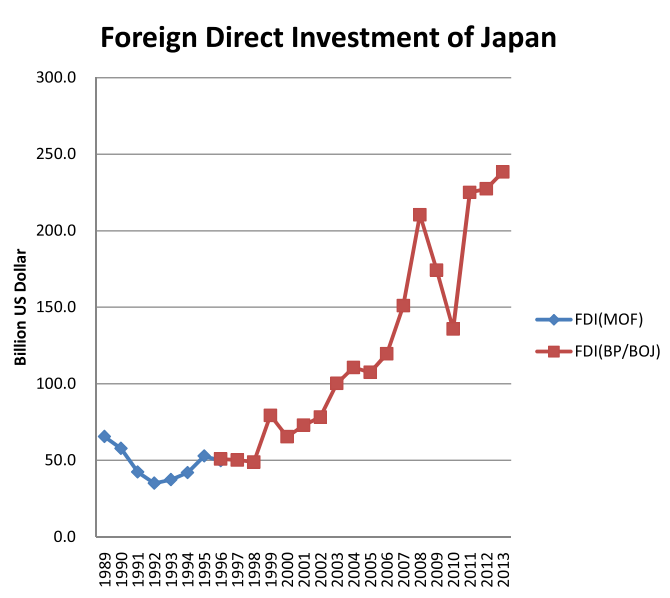

Japanese Overases Production, 2007

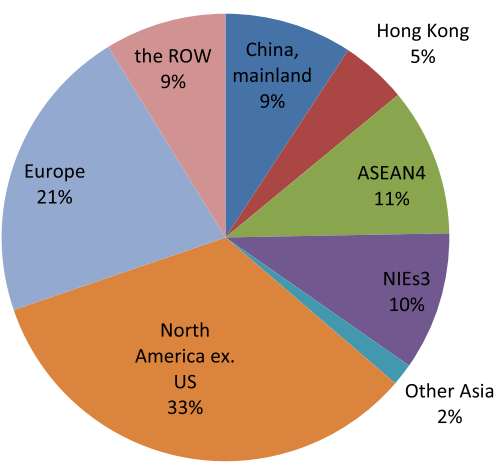

an important role in this expansion. Figure 2 shows the trend of FDI in China after 1989, and the shares of investing countries in 2007. Though the FDI ratio to GDP has been declining after the peak of 1994, its values are still growing. The largest investment region is Hong Kong, at 38 percent, with the investments from Asian countries being more than half, while Japan's investment in China was about 5 percent.

The economic interdependence between Japan and China has been strengthened more and more through international trade and direct investment. The Japan-China Input-Output Tables are one of the important tools used to investigate such relations. Here we will focus on the production activities of Japanese subsidiaries in China, and investigate the role of Japanese firms in the economic relations between Japan and China, revising the Japan-China International Input-Output Table to include production activities of Japanese subsidiaries in China as distinct sectors.

Global value chains or the international fragmentation of production across counties are one of the hot issues, and inter-countries input-output tables, as World InputOutput Database (Timmer et al. 2012), OECD Inter-Country Input-Output Model (Working Party of the Trade Committee, OECD 2012) and Asia International Input- 
Fig. 2 Data Source: National Bureau of Statistics of China, China Statistical Yearbook

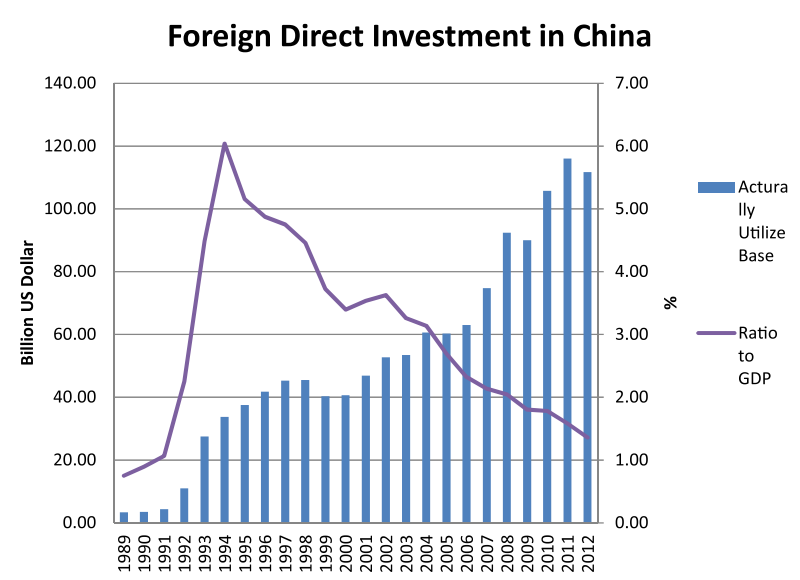

Regional Share of Foreign Direct Investment in China, 2007

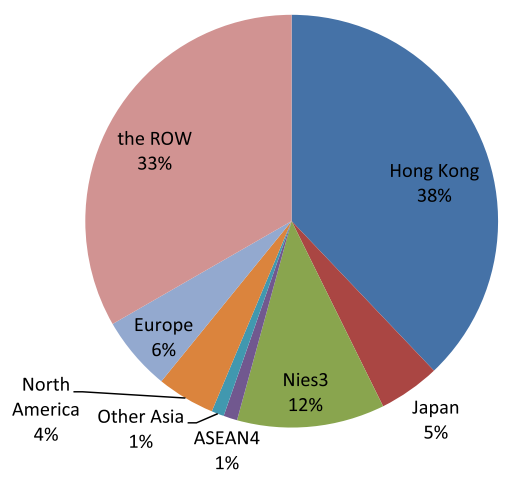

Output Table (IDE-Jetro 2013) are developed as tools to investigate such issues. As shown in Yang et al. (2012) and Koopman et al. (2012), the role of processing trade is important for the analysis of international trade in China. ${ }^{1}$ However, we concentrate our attention on the interdependence between two countries, Japan and China, especially through the production activity of Japanese Subsidiaries in China.

The basic idea of revising an international input-output table to include Japanese overseas activities as distinct sectors was proposed in Yamada (2002). In those papers, using the 1995 Japan-US International Input-Output Table of METI, we investigated the impact analysis of Japanese overseas production in the US on the Japanese economy. METI (2005) applied this analytical framework to their research using the 2000 Japan-US International Input-Output Table. Yamada (2004) produced a comparative

\footnotetext{
${ }^{1}$ Their papers separated the processing export from the rest of domestic production activity using microdata of the Customs office and manufacturing census. The merchandise trade data in Chinese Customs include a code for firm characteristics such as foreign-owned, processing trade zone firms and domestic enterprises.
} 
analysis of the overseas production activities of Japanese subsidiaries in the US and Asia, using the 1995 and 2000 IDE Asia International Input-Output Tables. Teng and Fang (2008) applied a somewhat similar analytical framework to Japan-China relations, using 1995 and 2000 Japan-China International Input-Output Tables which were estimated by them. This paper does the same using the following two characteristics: to apply the latest economic structures of the 2007 Japan-China International Input-Output Table, and to use the microdata of the Basic Survey of Overseas Business Activities, METI, Japan. ${ }^{2}$

The production activity of foreign affiliates in some country is highly correlated with inward FDI. FDI augments capital stock, which expand the potential capacity of production. Here repatriation of the operation surplus, induced by the production, to the investing country is expected. Some reinvestment also has to be considered. However, in this paper, we ignore the possible endogenous relation between the production and investment, mainly because of the weakness of the database to express that relation.

In the next section, we discuss the theoretical framework of a revised Japan-China International Input-Output Analysis on Japanese Overseas Production. In the third section, the method used to reconstruct the input-output table for the analysis will be explained briefly. Value-added and imports, that are induced by one unit of final demand, are analyzed in Sect. 4. Some simulation analysis on the production shift of Japanese firms from Japan and China are examined in Sect. 5. Section 6 is the conclusion.

\section{Theoretical Model}

A typical international input-output table for two countries is expressed as Table 1. Here, the suffix "J" means Japan, and the suffix "C" China. The vector $\mathbf{x}_{i}$ means output of the $i$ th country, and matrix $\mathbf{X}_{i j}$ is an intermediate input matrix, showing the input of $i$ th country's products in $j$ th country's activities. Vector $\mathbf{F}_{i j}$ indicates a final demand of the $i$ th country's products in the $j$ th country. Vectors $\mathbf{E}_{i}$ and $\mathbf{M}_{i}$ denote the export and import of the $i$ th country's products to the rest of the world (ROW), respectively.

Here we focus on Japanese overseas production in China. Those activities are included in the Chinese transactions. Thus, output vector $\mathbf{x}_{\mathrm{C}}$ can be divided into two vectors; $\mathbf{x}_{\mathrm{N}}$ for non-Japanese subsidiaries and $\mathbf{x}_{\mathrm{S}}$ for Japanese subsidiaries. Intermediate input matrices, final demand vector, and export vector of China can also be separated into the production activities of Japanese subsidiaries and others. When we treat Japanese subsidiaries in China as separate activities and express the suffix $\mathrm{N}$ for

\footnotetext{
${ }^{2}$ Our model, focusing on the overseas production of Japanese firms, differs from the enterprise inputoutput model as Albino et al. (2003), Marangoni et al. (2004), and Matsumoto and Fujimoto (2008). Albino et al. (2003) dealt with the production network of a local industrial district using an input-output model. Marangoni et al. (2004) considered the organizational structure of corporation groups, introducing new ideas on the control level and standardization of the organizational units. And Matsumoto and Fujimoto (2008) presented the micro and macro enterprise input-output model that captures in-company transactions and analyzed company-based $\mathrm{CO}_{2}$ emissions, directly and indirectly.
} 
Table 1 Japan-China international input-output table, METI

\begin{tabular}{|c|c|c|c|c|c|c|c|c|}
\hline & & \multicolumn{2}{|c|}{$\begin{array}{l}\text { Intermediate } \\
\text { demands }\end{array}$} & \multicolumn{2}{|c|}{$\begin{array}{l}\text { Final } \\
\text { demands }\end{array}$} & \multirow[t]{2}{*}{ Exports } & \multirow[t]{2}{*}{ Imports } & \multirow[t]{2}{*}{ Total output } \\
\hline & & Japan & China & Japan & China & & & \\
\hline \multirow{3}{*}{$\begin{array}{l}\text { Intermediate } \\
\text { inputs }\end{array}$} & Japan & $\mathbf{X}_{\mathrm{JJ}}$ & $\mathbf{X}_{\mathrm{JC}}$ & $\mathbf{F}_{\mathrm{JJ}}$ & $\mathbf{F}_{\mathrm{JC}}$ & $\mathbf{E}_{\mathrm{J}}$ & - & $\mathbf{X}_{\mathrm{J}}$ \\
\hline & China & $\mathbf{X}_{\mathrm{CJ}}$ & $\mathbf{X}_{\mathrm{CC}}$ & $\mathbf{F}_{\mathrm{CJ}}$ & $\mathbf{F}_{\mathrm{CC}}$ & $\mathbf{E}_{\mathrm{C}}$ & - & $\mathbf{X}_{\mathrm{C}}$ \\
\hline & ROW & $\mathbf{X}_{\mathrm{WJ}}$ & $\mathbf{X}_{\mathrm{WC}}$ & $\mathbf{F}_{\mathrm{WJ}}$ & $\mathbf{F}_{\mathrm{WC}}$ & - & $-\mathbf{M}_{\mathbf{J}}-\mathbf{M}_{\mathrm{C}}$ & - \\
\hline Value-added & & $\mathbf{V}_{\mathrm{J}}$ & $\mathbf{V}_{\mathrm{C}}$ & - & - & - & - & - \\
\hline Total input & & $\mathbf{X}_{\mathrm{J}}$ & $\mathbf{X}_{\mathrm{C}}$ & - & - & - & - & - \\
\hline
\end{tabular}

Table 2 Japan-China international input-output table (revised)

\begin{tabular}{|c|c|c|c|c|c|c|c|c|c|}
\hline & & \multicolumn{3}{|c|}{$\begin{array}{l}\text { Intermediate } \\
\text { demands }\end{array}$} & \multicolumn{2}{|c|}{$\begin{array}{l}\text { Final } \\
\text { demands }\end{array}$} & \multirow[t]{2}{*}{ Exports } & \multirow[t]{2}{*}{ Imports } & \multirow[t]{2}{*}{ Total outpu } \\
\hline & & Japan & China-NJS & China-JS & Japan & China & & & \\
\hline \multirow{4}{*}{$\begin{array}{l}\text { Intermediate } \\
\text { inputs }\end{array}$} & Japan & $\mathbf{X}_{\mathrm{JJ}}$ & $\mathbf{X}_{\mathrm{JN}}$ & $\mathbf{X}_{\mathrm{JS}}$ & $\mathbf{F}_{\mathrm{JJ}}$ & $\mathbf{F}_{\mathrm{JC}}$ & $\mathbf{E}_{J}$ & - & $\mathbf{X}_{\mathrm{J}}$ \\
\hline & China-NJS & $\mathbf{X}_{\mathrm{NJ}}$ & $\mathbf{X}_{\mathrm{NN}}$ & $\mathbf{X}_{\mathrm{NS}}$ & $\mathbf{F}_{\mathrm{NJ}}$ & $\mathbf{F}_{\mathrm{NC}}$ & $\mathbf{E}_{\mathrm{N}}$ & - & $\mathbf{X}_{\mathrm{N}}$ \\
\hline & China-JS & $\mathbf{X}_{\mathrm{SJ}}$ & $\mathbf{X}_{\mathrm{SN}}$ & $\mathbf{X}_{\mathrm{SS}}$ & $\mathbf{F}_{\mathrm{SJ}}$ & $\mathbf{F}_{\mathrm{SC}}$ & $\mathbf{E}_{\mathrm{S}}$ & - & $\mathbf{X}_{\mathrm{S}}$ \\
\hline & ROW & $\mathbf{X}_{\mathrm{WJ}}$ & $\mathbf{X}_{\mathrm{WN}}$ & $\mathbf{X}_{\mathrm{WS}}$ & $\mathbf{F}_{\mathrm{WJ}}$ & $\mathbf{F}_{\mathrm{WC}}$ & - & $-\mathbf{M}_{\mathrm{J}}-\mathbf{M}_{\mathrm{C}}$ & - \\
\hline Value-added & & $\mathbf{V}_{\mathbf{J}}$ & $\mathbf{V}_{\mathrm{N}}$ & $\mathbf{v}_{\mathrm{S}}$ & - & - & - & - & - \\
\hline Total input & & $\mathbf{X}_{\mathrm{J}}$ & $\mathbf{X}_{\mathrm{N}}$ & $\mathbf{X}_{\mathrm{S}}$ & - & - & - & - & - \\
\hline
\end{tabular}

China without Japanese subsidiaries, and suffix S for Japanese subsidiaries in China, the input-output table in Table 1 is revised as Table 2. Hereafter, we express China without Japanese subsidiaries as "China-NJS" and Japanese subsidiaries in China as "China-JS." China means both China-NJS and China-JS.

In Table 2, $\mathbf{X}_{i \mathrm{~S}}$ shows the intermediate input of China-JS from each country or region. Some inputs are imported from Japan, some are obtained from the local market in China, and some are from the ROW. $\mathbf{F}_{i \mathrm{C}}$ designates the final demands of China, in which the investments of Japanese subsidiaries are included. Some machines are imported from Japan, while others are obtained in China or from the ROW.

Our purpose is to recompile the input-output table in Table 1 to extract the activities of Japanese subsidiaries in China, using the METI survey database. However, though total investment of China-JS can be estimated, it is difficult to subdivide the total value into each product. We have scant information on how much investment is obtained from each region; Japan, China, and the ROW. Thus, we have to concentrate our attention on the input structure of China-JS, shown as Table 2, where there is no separation in the final demand of Japanese subsidiaries.

The input-output model for Table 2 is expressed as follows:

$$
\left[\begin{array}{c}
\mathbf{x}_{\mathrm{J}} \\
\mathbf{x}_{\mathrm{N}} \\
\mathbf{x}_{\mathrm{S}}
\end{array}\right]=\left[\begin{array}{lll}
\mathbf{A}_{\mathrm{JJ}} & \mathbf{A}_{\mathrm{JN}} & \mathbf{A}_{\mathrm{JS}} \\
\mathbf{A}_{\mathrm{NJ}} & \mathbf{A}_{\mathrm{NN}} & \mathbf{A}_{\mathrm{NS}} \\
\mathbf{A}_{\mathrm{SJ}} & \mathbf{A}_{\mathrm{SN}} & \mathbf{A}_{\mathrm{SS}}
\end{array}\right]\left[\begin{array}{c}
\mathbf{x}_{\mathrm{J}} \\
\mathbf{x}_{\mathrm{N}} \\
\mathbf{x}_{\mathrm{S}}
\end{array}\right]+\left[\begin{array}{c}
\mathbf{D}_{\mathrm{J}} \\
\mathbf{D}_{\mathrm{N}} \\
\mathbf{D}_{\mathrm{S}}
\end{array}\right],
$$


where

$$
\left[\begin{array}{c}
\mathbf{D}_{\mathrm{J}} \\
\mathbf{D}_{\mathrm{N}} \\
\mathbf{D}_{\mathrm{S}}
\end{array}\right]=\left[\begin{array}{c}
\mathbf{F}_{\mathrm{JJ}} \\
\mathbf{F}_{\mathrm{NJ}} \\
\mathbf{F}_{\mathrm{SJ}}
\end{array}\right]+\left[\begin{array}{c}
\mathbf{F}_{\mathrm{JC}} \\
\mathbf{F}_{\mathrm{NC}} \\
\mathbf{F}_{\mathrm{SC}}
\end{array}\right]+\left[\begin{array}{c}
\mathbf{E}_{\mathrm{J}} \\
\mathbf{E}_{\mathrm{N}} \\
\mathbf{E}_{\mathrm{S}}
\end{array}\right],
$$

and matrix $\mathbf{A}_{i j}$ means input coefficient matrix of the $j$ th country on the $i$ th country's product. Solving Eq. (1), we obtain the output $\left[\Delta \mathbf{x}_{\mathrm{J}} \Delta \mathbf{x}_{\mathrm{N}} \Delta \mathbf{x}_{\mathrm{S}}\right]^{\prime}$ determined by some final demands $\left[\Delta \mathbf{D}_{\mathrm{J}} \Delta \mathbf{D}_{\mathrm{N}} \Delta \mathbf{D}_{\mathrm{S}}\right]^{\prime}$ as Eq. (2):

$$
\left[\begin{array}{c}
\Delta \mathbf{x}_{\mathrm{J}} \\
\Delta \mathbf{x}_{\mathrm{N}} \\
\Delta \mathbf{x}_{\mathrm{S}}
\end{array}\right]=\left[\begin{array}{ccc}
\mathbf{B}_{\mathrm{JJ}} & \mathbf{B}_{\mathrm{JN}} & \mathbf{B}_{\mathrm{JS}} \\
\mathbf{B}_{\mathrm{NJ}} & \mathbf{B}_{\mathrm{NN}} & \mathbf{B}_{\mathrm{NS}} \\
\mathbf{B}_{\mathrm{SJ}} & \mathbf{B}_{\mathrm{SN}} & \mathbf{B}_{\mathrm{SS}}
\end{array}\right]\left[\begin{array}{c}
\Delta \mathbf{D}_{\mathrm{J}} \\
\Delta \mathbf{D}_{\mathrm{N}} \\
\Delta \mathbf{D}_{\mathrm{S}}
\end{array}\right] .
$$

In this equation, matrix $\mathbf{B}_{i j}$ is a sub-matrix of the Leontief inverse matrix. Multiplying the value-added coefficient matrix $\hat{\mathbf{V}}_{i}$, that is a diagonal matrix of each valueadded coefficient, and the import coefficient matrix $\mathbf{A}_{\mathrm{W} j}$ to the output vector, the corresponding value-added vectors and import vectors are reduced, respectively.

$$
\begin{gathered}
{\left[\begin{array}{c}
\Delta \mathbf{V}_{\mathrm{J}} \\
\Delta \mathbf{V}_{\mathrm{N}} \\
\Delta \mathbf{V}_{\mathrm{S}}
\end{array}\right]=\left[\begin{array}{ccc}
\hat{\mathbf{V}}_{\mathrm{J}} \mathbf{B}_{\mathrm{JJ}} & \hat{\mathbf{V}}_{\mathrm{J}} \mathbf{B}_{\mathrm{JN}} & \hat{\mathbf{V}}_{\mathrm{J}} \mathbf{B}_{\mathrm{JS}} \\
\hat{\mathbf{V}}_{\mathrm{N}} \mathbf{B}_{\mathrm{NJ}} & \hat{\mathbf{V}}_{\mathrm{N}} \mathbf{B}_{\mathrm{NN}} & \hat{\mathbf{V}}_{\mathrm{N}} \mathbf{B}_{\mathrm{NS}} \\
\hat{\mathbf{V}}_{\mathrm{S}} \mathbf{B}_{\mathrm{SJ}} & \hat{\mathbf{V}}_{\mathrm{S}} \mathbf{B}_{\mathrm{SN}} & \hat{\mathbf{V}}_{\mathrm{S}} \mathbf{B}_{\mathrm{SS}}
\end{array}\right]\left[\begin{array}{c}
\Delta \mathbf{D}_{\mathrm{J}} \\
\Delta \mathbf{D}_{\mathrm{N}} \\
\Delta \mathbf{D}_{\mathrm{S}}
\end{array}\right],} \\
{\left[\begin{array}{c}
\Delta \mathbf{M}_{\mathrm{J}} \\
\Delta \mathbf{M}_{\mathrm{N}} \\
\Delta \mathbf{M}_{\mathrm{S}}
\end{array}\right]=\left[\begin{array}{ccc}
\mathbf{A}_{\mathrm{WJ}} \mathbf{B}_{\mathrm{JJ}} & \mathbf{A}_{\mathrm{WJ}} \mathbf{B}_{\mathrm{JN}} & \mathbf{A}_{\mathrm{WJ}} \mathbf{B}_{\mathrm{JS}} \\
\mathbf{A}_{\mathrm{WN}} \mathbf{B}_{\mathrm{NJ}} & \mathbf{A}_{\mathrm{WN}} \mathbf{B}_{\mathrm{NN}} & \mathbf{A}_{\mathrm{WN}} \mathbf{B}_{\mathrm{NS}} \\
\mathbf{A}_{\mathrm{WS}} \mathbf{B}_{\mathrm{SJ}} & \mathbf{A}_{\mathrm{WS}} \mathbf{B}_{\mathrm{SN}} & \mathbf{A}_{\mathrm{WS}} \mathbf{B}_{\mathrm{SS}}
\end{array}\right]\left[\begin{array}{c}
\Delta \mathbf{D}_{\mathrm{J}} \\
\Delta \mathbf{D}_{\mathrm{N}} \\
\Delta \mathbf{D}_{\mathrm{S}}
\end{array}\right] .}
\end{gathered}
$$

Here, the sum of the value-added and import demands induced by some independent change in the final demand equals the value of the total change. We can evaluate the contributions of each region in terms of the induced value-added and import demands.

In Eq. (2), the final goods produced in Japan are comprised of three parts; the demand of domestic markets in Japan $\mathbf{F}_{\mathrm{JJ}}$, exports to China $\mathbf{F}_{\mathrm{JC}}$, and exports to ROW $\mathbf{E}_{\mathrm{J}}$. Any change to these three parts affects not only the Japanese production but also the production in China-NJS, as well as China-JS. Such impacts on value-added, directly and indirectly, are evaluated by setting the final demands in Eq. (2) as follows:

$$
\left[\begin{array}{lll}
\Delta \mathbf{D}_{\mathrm{J}} & \Delta \mathbf{D}_{\mathrm{N}} & \Delta \mathbf{D}_{\mathrm{S}}
\end{array}\right]^{\prime}=\left[\begin{array}{lll}
\mathbf{e} & \mathbf{0} & \mathbf{0}
\end{array}\right]^{\prime},
$$

where e shows a one-unit change of some sector in Japan. Similarly, we can evaluate the effects of a one-unit change in China-NJS, and China-JS, respectively, on valueadded as follows:

$$
\begin{aligned}
& {\left[\begin{array}{lll}
\Delta \mathbf{D}_{\mathrm{J}} & \Delta \mathbf{D}_{\mathrm{N}} & \Delta \mathbf{D}_{\mathrm{S}}
\end{array}\right]^{\prime}=\left[\begin{array}{lll}
\mathbf{0} & \mathbf{e} & \mathbf{0}
\end{array}\right]^{\prime},} \\
& {\left[\begin{array}{lll}
\Delta \mathbf{D}_{\mathrm{J}} & \Delta \mathbf{D}_{\mathrm{N}} & \Delta \mathbf{D}_{\mathrm{S}}
\end{array}\right]^{\prime}=\left[\begin{array}{lll}
\mathbf{0} & \mathbf{0} & \mathbf{e}
\end{array}\right]^{\prime} .}
\end{aligned}
$$

Here we obtain the effect of a production shift by Japanese firms to China, reducing one unit of final demand in Japan, and increasing one unit of final demand in the 
corresponding sector of China-JS. In this case, the final demands vector is expressed as

$$
\left[\begin{array}{lll}
\Delta \mathbf{D}_{\mathrm{J}} & \Delta \mathbf{D}_{\mathrm{N}} & \Delta \mathbf{D}_{\mathrm{S}}
\end{array}\right]^{\prime}=\left[\begin{array}{lll}
-\mathbf{e} & \mathbf{0} & \mathbf{e}
\end{array}\right]^{\prime} .
$$

On the other hand, the final goods that are produced in Japan might be substituted by those that are produced by Chinese firms. Such an effect is calculated by setting the final demands as follows:

$$
\left[\begin{array}{lll}
\Delta \mathbf{D}_{\mathrm{J}} & \Delta \mathbf{D}_{\mathrm{N}} & \Delta \mathbf{D}_{\mathrm{S}}
\end{array}\right]^{\prime}=\left[\begin{array}{lll}
-\mathbf{e} & \mathbf{e} & \mathbf{0}
\end{array}\right]^{\prime}
$$

\section{Reconstruction of Japan-China International Input-Output Table}

In this section, we discuss the method used to reconstruct an input-output table suitable to treat Japanese overseas production as an explicit sector. We modify the original input-output table in Table 1 to the one in Table 2. Comparing each definition of sectors between the 2007 Japan-China International Input-Output Table and the Survey of Overseas Business Activities of METI, we first compiled the input-output table from 77 sectors into 63 sectors. Then, applying the information of the METI survey microdata on sales and procurement of Japanese subsidiaries in China, we reconstructed the table. ${ }^{3}$

From the METI survey database, we were able to acquire the following information. First, we regarded the sales values of each sector in China-JS as product values, $\mathbf{X}_{S}$, ignoring the change of inventory. ${ }^{4}$ Then we obtained the output of China-NJS, $\mathbf{X}_{\mathrm{N}}$, by subtracting the output of China-JS, $\mathbf{X}_{\mathrm{S}}$, from Chinese output, $\mathbf{X}_{\mathrm{C}}$.

The intermediate input matrix, $\mathbf{X}_{\mathrm{CC}}$, has to be decomposed to the following four matrices; $\mathbf{X}_{\mathrm{NN}}, \mathbf{X}_{\mathrm{SN}}, \mathbf{X}_{\mathrm{SN}}$, and $\mathbf{X}_{\mathrm{SS}}$. We chose the strategy to divide $\mathbf{X}_{\mathrm{CC}}$ into the two matrices, $\mathbf{X}_{\mathrm{CN}}$ and $\mathbf{X}_{\mathrm{CS}}$, first. Here, $\mathbf{X}_{\mathrm{CN}}$ denotes the intermediate input of ChinaNJS from China overall, and $\mathbf{X}_{\mathrm{CS}}$ means the intermediate input of China-JS from China overall. Then we disintegrate $\mathbf{X}_{\mathrm{CN}}$ to $\mathbf{X}_{\mathrm{NN}}$ and $\mathbf{X}_{\mathrm{SN}}$, and $\mathbf{X}_{\mathrm{CS}}$ to $\mathbf{X}_{\mathrm{NS}}$ and $\mathbf{X}_{\mathrm{SS}}$, respectively.

Assuming the ratio of the purchase values of intermediate goods to total sales values to be equal to the intermediate input ratio, we were able to estimate the total value of the intermediate input for each sector of a Japanese subsidiary. That was equal to the total value of column-sums of $\mathbf{X}_{\mathrm{IS}}, \mathbf{X}_{\mathrm{CS}}$, and $\mathbf{X}_{\mathrm{WS}}$ for each sector. We obtained

\footnotetext{
${ }^{3}$ Sample sizes for China (mainland) are 3,521 and 3,781 for the 2006 and 2007 Overseas Business Surveys, METI, respectively. Survey data are fiscal years. Among them we chose the 3,332 and 3,648 samples, respectively, omitting the data that lack information on sales values. We calculated, for each year, the sales and purchasing of intermediate goods by region for 63 sectors. There are differences in sample sizes by sector for two years. So we calculated the sales and purchasing values of calendar years as a weight average of two-year values, after adjusting the size of 2006 to suit that of 2007.

${ }^{4}$ The difference between sales and products is a change in inventory of products. However, since we were unable to acquire the information of the inventory on Japanese subsidiaries. We adopted the assumption that there was no change in inventory, which stated that sales value was equal to product value. However, for the "Wholesale and retail trades" sector, we established the product value as the difference between the sales value and purchasing goods.
} 
the column sum of the value-added, $\mathbf{V}_{\mathrm{S}}$, subtracting the sum of each intermediate input from the output value, $\mathbf{X}_{\mathrm{S}}$.

We were then able to acquire each sectoral input value from Japan, China, and the ROW, multiplying the regional purchasing ratio (which is calculated from the METI survey database), to the total intermediate input values by sector. They are the column-sums of $\mathbf{X}_{\mathrm{JS}}, \mathbf{X}_{\mathrm{CS}}, \mathbf{X}_{\mathrm{WS}}$, respectively. From the METI database, we were able to obtain more detailed information on the purchasing of intermediate input goods from a Japanese or non-Japanese firm. ${ }^{5}$ Using that information, we could divide the total purchasing value in China, $\mathbf{X}_{\mathrm{CS}}$, into two parts; one from China-JS, which is the column-sum of $\mathbf{X}_{\mathrm{SS}}$, and the other from China-NJS, i.e. the column-sum of $\mathbf{X}_{\mathrm{NS}}$.

To estimate each cell value of the input structure, we needed more detailed information. Thus, we used the elements of the actual input vector as reference indices to share the total value into each cell value. For example, each cell value of $\mathbf{X}_{\mathrm{IS}}$ was obtained by multiplying the column share $a_{i k}^{\mathrm{JC}} / \sum_{j} a_{j k}^{\mathrm{JC}}$ of $\mathbf{X}_{\mathrm{JC}}$ to the column sum of $\mathbf{X}_{\mathrm{IS}}$, which we had already estimated. Similarly, each cell value of $\mathbf{X}_{\mathrm{WS}}$ was calculated by multiplying the column share $a_{i k}^{\mathrm{WC}} / \sum_{j} a_{j k}^{\mathrm{WC}}$ of $\mathbf{X}_{\mathrm{WC}}$ to the column sum of $\mathbf{X}_{\mathrm{WS}}$, which was also already estimated.

Returning to the row-wise aspect of demand-supply, we were able to acquire regional sales shares ${ }^{6}$ by sector from the METI survey database. Using those shares, we estimated the regional sales values to Japan, China, and the ROW, which corresponded to the row-sum values of $\left(\mathbf{X}_{\mathrm{SJ}}\right.$ and $\left.\mathbf{F}_{\mathrm{SJ}}\right),\left(\mathbf{X}_{\mathrm{SN}}, \mathbf{X}_{\mathrm{SS}}\right.$ and $\left.\mathbf{F}_{\mathrm{SC}}\right)$, and $\mathbf{E}_{\mathrm{S}}$, respectively. The METI database gave us the information on how much the share of intermediate goods was to the total output for each sector. ${ }^{7}$ We could then divide the row-sum value of $\left(\mathbf{X}_{\mathrm{SJ}}\right.$ and $\left.\mathbf{F}_{\mathrm{SJ}}\right)$ into the row-sum of the intermediate demand $\mathbf{X}_{\mathrm{SJ}}$ and the row-sum of the final demand $\mathbf{F}_{\mathrm{SJ}}$. Similarly, for the sales in China, we could set separate values for the row-sum of $\left(\mathbf{X}_{\mathrm{SN}}\right.$ and $\left.\mathbf{X}_{\mathrm{SS}}\right)$ and $\mathbf{F}_{\mathrm{SC}}$. Further information on how much Japanese subsidiaries sell to other Japanese subsidiaries in China by sector was available from the METI database. ${ }^{8}$ Thus, here we used these sales ratios to separate the row-sum values of $\mathbf{X}_{\mathrm{NS}}$ and $\mathbf{X}_{\mathrm{SS}}$ from the row-sum values of $\mathbf{X}_{\mathrm{CS}}$ by sector.

\footnotetext{
${ }^{5}$ This ratio is also the value for the 2009 survey data. Thus, we applied similar modification as we used for the ratio sold for Japanese subsidiaries.

${ }^{6}$ There are firms that do not assign sales values by regions, but that answer the value for total sales. We have calculated the regional sales ratio by excluding such firms.

${ }^{7}$ The information of "the share of intermediate goods and final goods among sales" is obtained only after the 2008 survey. We applied the METI for us to use microdata of the 2008 and 2009 surveys. However, we were not able to obtain permission, so we had to use published data from the 2008 and 2009 survey reports. Two problems must be resolved. First, these data are more aggregated by sector than that we defined. So we used these data with some modifications. Second, the published data on the share of intermediate goods and final goods show those of firms that produce mainly intermediate goods or final goods. We had better use these shares as weighted value with the product values as the weight, which are only possible by using the microdata.

8"Sales to Japanese subsidiaries in China" were newly added as an item in the 2009 questionnaire. This information is very important for estimating the transaction among Japanese subsidiaries in China. Unfortunately, we were not able to acquire permission to use the microdata of the 2009 survey in spite of our application. So we had to use the officially aggregated data in the 2009 survey report with the same modifications.
} 
We calculated the value for each cell of $\mathbf{X}_{\mathrm{SJ}}$ by assuming that the export pattern of intermediate goods from China to Japan showed no difference between Japanese subsidiaries and the other firms. Also, the values for each cell of final goods $\mathbf{F}_{\mathrm{SJ}}, \mathbf{F}_{\mathrm{SC}}$ were determined by assuming that the shares of consumption and investment were the same for any suppliers, whether Japanese subsidiaries or the other firms. ${ }^{9}$ For $\mathbf{X}_{\mathrm{SS}}$, which is the transaction matrix of intermediate goods between Japanese subsidiaries in China, both the column-sum and the row-sum were independently estimated for each sector. So we applied the RAS method ${ }^{10}$ to acquire the cell values of the matrix, with the corresponding input coefficients of the original input-output table as initial values, after arranging both sum values so that their sum is equal to their average.

The intermediate transaction matrices of China-NJS, $\mathbf{X}_{\mathrm{NJ}}, \mathbf{X}_{\mathrm{JN}}$, and $\mathbf{X}_{\mathrm{NN}}$ were obtained by subtraction of Japanese subsidiaries' values from Chinese values for each corresponding matrix just as $\mathbf{X}_{\mathrm{NJ}}=\mathbf{X}_{\mathrm{CJ}}-\mathbf{X}_{\mathrm{SJ}}$. However, since such an estimation gives inconsistent values in some sectors, we made some modifications. For example, for imports of Japan from Japanese subsidiaries, we did not use the METI survey's shares but the actual import shares in the original input-output table.

For each value-added sector, we estimated the sectoral compensation of employees by multiplying the ratio of the total salary of employees to the sales values from the METI survey database to the corresponding output value. The information on depreciation and indirect tax and subsidies was not available, so we estimated them by the actual ratio-to-output value for the corresponding sectors in China. The business surplus was estimated as the residual of the value-added sectors, by subtracting the item values cited above.

The reconstructed Japan-China input-output tables, transactions and input coefficients, are shown in Table 3, where all sectors are aggregated to one for each region. The transaction flows, output and value-added, appear in Fig. 3, where the output of Japan amounts to 8,190.0 billion US dollars, and the value-added was 4,197.4 billion US dollars. The exports from Japan to China-NJS were 29.9 billion US dollars and 89.4 billion US dollars for final goods and intermediate goods, respectively. Japan also imported final goods and intermediate goods of 63.1 billion US dollars and 40.2 billion US dollars, respectively, from China-NJS. The exports of intermediate goods of China-JS to Japan amounted to 20.3 billion US dollars, while the imports of final intermediate goods were 11.3 billion US dollars and 15.6 billion US dollars, respectively.

The output of China-NJS was 10,705.5 billion US dollars, and the value-added was 3,455.8 billion US dollars. On the other hand, the output of China-JS was 141.3 billion US dollars, and its value-added was 43.0 billion US dollars with purchases from Chinese firms of 50.7 billion US dollars, imports from Japan of 20.3 billion US dollars, and imports from the ROW of 10.1 billion US dollars. China-JS supplied intermediate goods and final goods to China-NJS, 35.9 billion US dollars and 38.8

\footnotetext{
${ }^{9}$ The final demand parts, consumption and investment, of Japanese subsidiary sectors were shared by using actual consumption and investment in Japan and China. The change in inventory was assumed to be zero for each sector with some exceptions. The final demand parts of non-Japanese firms were obtained by subtracting the estimated value of the Japanese subsidiaries from the value in China.

${ }^{10}$ Here we used the domestic input coefficient of China as our initial value, applying the same coefficient when we estimated the input coefficient of Japanese subsidiaries in China.
} 
Table 3 Reconstructed input-output table

(1) Value table

\begin{tabular}{|c|c|c|c|c|c|c|c|c|c|c|c|c|c|c|c|}
\hline & & \multicolumn{4}{|c|}{ Intermediate demand } & \multicolumn{3}{|l|}{ Japan } & \multicolumn{4}{|l|}{ China } & \multirow{2}{*}{$\begin{array}{l}\text { Total final } \\
\text { demand }\end{array}$} & \multirow[t]{2}{*}{ Imports } & \multirow{2}{*}{$\begin{array}{l}\text { Total } \\
\text { output }\end{array}$} \\
\hline & & Japan & China-NIS & China-JS & $\begin{array}{l}\text { Total } \\
\text { intermediate } \\
\text { demand }\end{array}$ & $\begin{array}{l}\text { Domestic } \\
\text { final demand }\end{array}$ & $\begin{array}{l}\text { Exports } \\
\text { to ROW }\end{array}$ & $\begin{array}{l}\text { Final } \\
\text { demand }\end{array}$ & $\begin{array}{l}\text { Domestic } \\
\text { final demand }\end{array}$ & $\begin{array}{l}\text { Exports } \\
\text { to ROW }\end{array}$ & Errors & $\begin{array}{l}\text { Final } \\
\text { demand }\end{array}$ & & & \\
\hline \multirow{7}{*}{$\begin{array}{l}\text { Intermediate } \\
\text { input }\end{array}$} & Japan & $3,452.3$ & 89.4 & 20.3 & $3,562.0$ & $3,952.8$ & 645.8 & $4,598.6$ & 29.3 & 0.0 & 0.0 & 29.3 & $4,628.0$ & 0.0 & $8,190.0$ \\
\hline & China-NJS & 40.2 & $6,349.8$ & 50.7 & $6,440.7$ & 63.1 & 0.0 & 63.1 & $2,987.5$ & $1,192.7$ & 23.6 & $4,203.8$ & $4,266.9$ & 0.0 & $10,707.5$ \\
\hline & China-JS & 15.6 & 35.9 & 16.8 & 68.4 & 11.3 & 0.0 & 11.3 & 38.8 & 22.8 & 0.0 & 61.6 & 72.9 & 0.0 & 141.3 \\
\hline & $\begin{array}{l}\text { Imports from } \\
\text { ROW }\end{array}$ & 460.4 & 760.4 & 10.1 & $1,231.0$ & 131.1 & 0.0 & 131.1 & 129.0 & 0.0 & 0.0 & 129.0 & 260.1 & $1,491.1$ & 0.0 \\
\hline & $\begin{array}{l}\text { Freight and } \\
\text { insurance } \\
\text { (Japan-China) }\end{array}$ & 1.6 & 2.4 & 0.1 & 4.1 & 1.5 & 0.0 & 1.5 & 0.5 & 0.0 & 0.0 & 0.5 & 2.0 & 6.1 & 0.0 \\
\hline & $\begin{array}{l}\text { Duties and import } \\
\text { commodity taxes }\end{array}$ & 32.4 & 13.9 & 0.3 & 46.6 & 17.0 & 0.0 & 17.0 & 6.9 & 0.0 & 0.0 & 6.9 & 23.9 & 70.5 & 0.0 \\
\hline & $\begin{array}{l}\text { Total } \\
\text { intermediate } \\
\text { input }\end{array}$ & $4,002.6$ & $7,251.8$ & 98.4 & $11,352.7$ & $4,176.7$ & 645.8 & $4,822.5$ & $3,192.1$ & $1,215.5$ & 23.6 & $4,431.2$ & $9,253.7$ & $1,567.6$ & $19,038.8$ \\
\hline $\begin{array}{l}\text { Total } \\
\text { value-added }\end{array}$ & & $4,187.4$ & $3,455.8$ & 43.0 & $7,686.1$ & & & & & & & & & & \\
\hline Total input & & $8,190.0$ & $10,707.5$ & 141.3 & $19,038.8$ & & & & & & & & & & \\
\hline
\end{tabular}

Unit: Billion US dollars 
Table 3 (Continued)

(2) Share table

\begin{tabular}{|c|c|c|c|c|c|c|c|c|c|c|c|c|c|c|c|}
\hline & & \multicolumn{4}{|c|}{ Intermediate demand } & \multicolumn{3}{|l|}{ Japan } & \multicolumn{4}{|l|}{ China } & \multirow{2}{*}{$\begin{array}{l}\text { Total final } \\
\text { demand }\end{array}$} & \multirow[t]{2}{*}{ Imports } & \multirow{2}{*}{$\begin{array}{l}\text { Total } \\
\text { output }\end{array}$} \\
\hline & & Japan & China-NJS & China-JS & $\begin{array}{l}\text { Total } \\
\text { intermediate } \\
\text { demand }\end{array}$ & $\begin{array}{l}\text { Domestic } \\
\text { final demand }\end{array}$ & $\begin{array}{l}\text { Exports } \\
\text { to ROW }\end{array}$ & $\begin{array}{l}\text { Final } \\
\text { demand }\end{array}$ & $\begin{array}{l}\text { Domestic } \\
\text { final demand }\end{array}$ & $\begin{array}{l}\text { Exports } \\
\text { to ROW }\end{array}$ & Errors & $\begin{array}{l}\text { Final } \\
\text { demand }\end{array}$ & & & \\
\hline \multirow{7}{*}{$\begin{array}{l}\text { Intermediate } \\
\text { input }\end{array}$} & Japan & 0.422 & 0.008 & 0.144 & 0.187 & 0.946 & 1.000 & 0.954 & 0.009 & 0.000 & 0.000 & 0.007 & 0.500 & 0.000 & 0.430 \\
\hline & China-NJS & 0.005 & 0.593 & 0.358 & 0.338 & 0.015 & 0.000 & 0.013 & 0.936 & 0.981 & 1.000 & 0.949 & 0.461 & 0.000 & 0.562 \\
\hline & China-JS & 0.002 & 0.003 & 0.119 & 0.004 & 0.003 & 0.000 & 0.002 & 0.012 & 0.019 & 0.000 & 0.014 & 0.008 & 0.000 & 0.007 \\
\hline & $\begin{array}{l}\text { Imports from } \\
\text { ROW }\end{array}$ & 0.056 & 0.071 & 0.072 & 0.065 & 0.031 & 0.000 & 0.027 & 0.040 & 0.000 & 0.000 & 0.029 & 0.028 & 0.951 & 0.000 \\
\hline & $\begin{array}{l}\text { Freight and } \\
\text { insurance } \\
\text { (Japan-China) }\end{array}$ & 0.000 & 0.000 & 0.000 & 0.000 & 0.000 & 0.000 & 0.000 & 0.000 & 0.000 & 0.000 & 0.000 & 0.000 & 0.004 & 0.000 \\
\hline & $\begin{array}{l}\text { Duties and } \\
\text { Import } \\
\text { commodity taxes }\end{array}$ & 0.004 & 0.001 & 0.002 & 0.002 & 0.004 & 0.000 & 0.004 & 0.002 & 0.000 & 0.000 & 0.002 & 0.003 & 0.045 & 0.000 \\
\hline & $\begin{array}{l}\text { Total } \\
\text { intermediate } \\
\text { input }\end{array}$ & 0.489 & 0.677 & 0.696 & 0.596 & 1.000 & 1.000 & 1.000 & 1.000 & 1.000 & 1.000 & 1.000 & 1.000 & 1.000 & 1.000 \\
\hline $\begin{array}{l}\text { Total } \\
\text { Value-added }\end{array}$ & & 0.511 & 0.323 & 0.304 & 0.404 & & & & & & & & & & \\
\hline Total input & & 1.000 & 1.000 & 1.000 & 1.000 & & & & & & & & & & \\
\hline
\end{tabular}




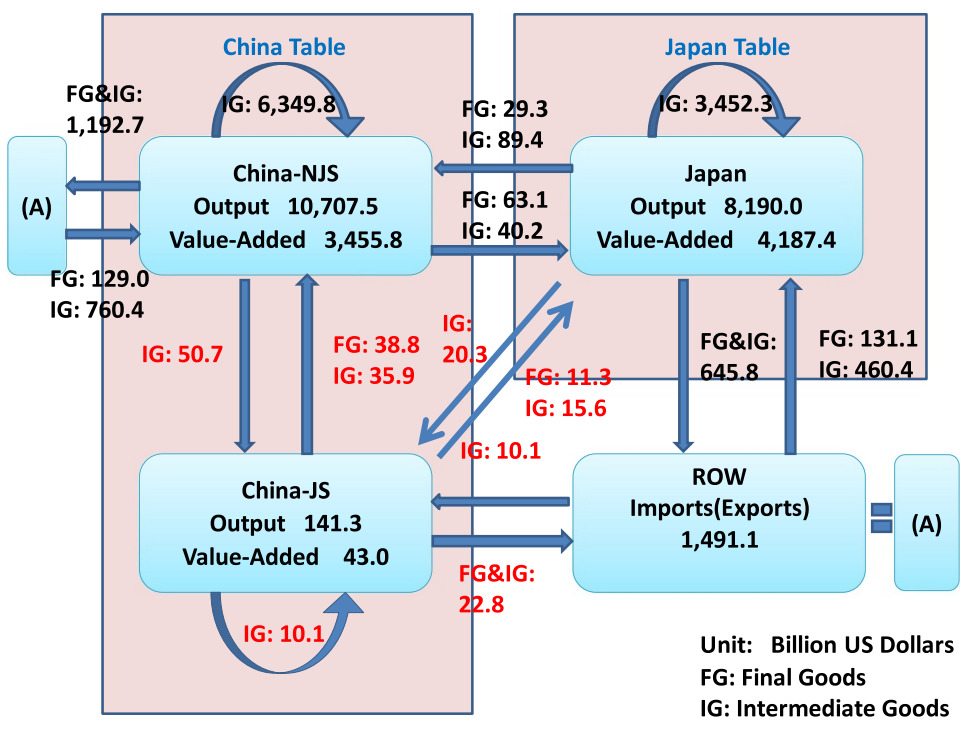

Fig. 3 Demand and supply of products between Japan and China

billion US dollars, respectively. They exported intermediate goods and final goods to Japan, 15.6 billion US dollars and 11.3 billion US dollars, respectively, and exported to the ROW 228 billion US dollars.

In Table 3, the average value-added ratio to the total product is 0.304 for ChinaJS. The ratio is almost the same as that of China-NJS, 0.323, and differs from that of Japan, 0.511. It seems a bit curious in the sense that the technology adopted in ChinaJS is not similar to that of Japan. However, the average ratio within manufacturing sectors is 0.291 for China-JS, which is larger than that of China-NJS, 0.209, and is similar to that of Japan, 0.315. This happens because the share of the tertiary sector, which usually has a high value-added ratio, is not so large as that in China-NJS.

Table 4 shows the final goods of China-JS by 30 sectors; exports to Japan, the domestic demand of China, and exports to the ROW. Their shares by regions also appear for each sector. From the figures, we observed the following characteristics. First, the dominant sectors are "General machinery," "Household electronic equipment, and communications equipment," "Household electric and non-electric equipment," "Electronic components," "Industrial electric equipment," and "Motor vehicles." Though "General machinery" and almost all sectors in electrical machinery industries supply almost equally to all regions; China, Japan, and the ROW. The "Electronic components" sector sells only to the ROW because the products of this sector are mainly intermediate goods rather than final goods. In contrast, sales of "Motor vehicles," which is mainly final goods, are concentrated in the Chinese market. "Food" supplies are sold mainly to the Chinese market, while "Textiles, apparel and leather products" are sold mostly to Japan. "Chemical products" and "Steel, nonsteel metals, and metal products" do not supply the Japanese market, but rather the Chinese and the ROW markets. 
Table 4 Final products of Japanese subsidiaries in China

\begin{tabular}{|c|c|c|c|c|c|c|c|c|c|}
\hline & & \multicolumn{4}{|c|}{ Final products } & \multicolumn{4}{|l|}{ Shares } \\
\hline & & Japan & China & ROW & Total & Japan & China & ROW & Total \\
\hline 1 & Agriculture, forestry, husbandry & 0.00 & 0.00 & 0.00 & 0.00 & 18.4 & 81.3 & 0.4 & 100.0 \\
\hline 2 & Fishery & 0.00 & 0.02 & 0.05 & 0.07 & 6.2 & 23.7 & 70.0 & 100.0 \\
\hline 3 & Mining & 0.00 & 0.00 & 0.00 & 0.00 & 99.9 & 0.1 & 0.0 & 100.0 \\
\hline 4 & Food & 0.18 & 2.35 & 0.10 & 2.63 & 7.0 & 89.1 & 3.8 & 100.0 \\
\hline 5 & Textiles, apparel, and leather products & 1.01 & 0.24 & 0.50 & 1.74 & 57.9 & 13.6 & 28.5 & 100.0 \\
\hline 6 & $\begin{array}{l}\text { Lumber, wood products, paper and } \\
\text { printing }\end{array}$ & 0.04 & 0.02 & 0.04 & 0.10 & 42.7 & 17.5 & 39.7 & 100.0 \\
\hline 7 & Chemical products & 0.08 & 0.35 & 0.75 & 1.18 & 6.7 & 29.6 & 63.7 & 100.0 \\
\hline 8 & Plastic and rubber products & 0.17 & 0.04 & 0.31 & 0.52 & 33.5 & 7.6 & 58.9 & 100.0 \\
\hline 9 & Petroleum and coal products & 0.00 & 0.00 & 0.00 & 0.01 & 0.0 & 40.5 & 59.5 & 100.0 \\
\hline 10 & Non-metal products & 0.02 & 0.01 & 0.20 & 0.24 & 10.4 & 3.7 & 85.9 & 100.0 \\
\hline 11 & $\begin{array}{l}\text { Steel, non-steel metals, and metal } \\
\text { products }\end{array}$ & 0.15 & 0.13 & 1.07 & 1.35 & 11.3 & 9.5 & 79.2 & 100.0 \\
\hline 12 & General machinery & 1.66 & 2.51 & 3.22 & 7.39 & 22.5 & 33.9 & 43.6 & 100.0 \\
\hline 13 & $\begin{array}{l}\text { Household electronic equipment, and } \\
\text { communications equipment }\end{array}$ & 3.09 & 4.00 & 2.91 & 10.01 & 30.9 & 40.0 & 29.1 & 100.0 \\
\hline 14 & $\begin{array}{l}\text { Household electric and non-electric } \\
\text { equipment }\end{array}$ & 2.06 & 6.60 & 2.81 & 11.47 & 18.0 & 57.5 & 24.5 & 100.0 \\
\hline 15 & Electronic components & 0.01 & -0.03 & 5.66 & 5.63 & 0.1 & -0.5 & 100.4 & 100.0 \\
\hline 16 & Industrial electric equipment & 0.60 & 2.07 & 1.87 & 4.54 & 13.2 & 45.5 & 41.3 & 100.0 \\
\hline 17 & $\begin{array}{l}\text { Electronic computing equipment and } \\
\text { accessories }\end{array}$ & 0.54 & 0.23 & 0.05 & 0.81 & 66.2 & 27.9 & 5.9 & 100.0 \\
\hline 18 & Motor vehicles & 0.00 & 15.41 & 0.18 & 15.60 & 0.0 & 98.8 & 1.2 & 100.0 \\
\hline 19 & Motor vehicle parts & 0.09 & 0.19 & 1.19 & 1.47 & 6.0 & 13.1 & 80.9 & 100.0 \\
\hline 20 & Other transportation equipment & 0.12 & 0.04 & 0.61 & 0.77 & 15.3 & 5.4 & 79.3 & 100.0 \\
\hline 21 & Precision instruments & 0.92 & 0.05 & 0.14 & 1.11 & 82.9 & 4.5 & 12.6 & 100.0 \\
\hline 22 & $\begin{array}{l}\text { Other miscellaneous manufacturing } \\
\text { (incl. reuse and recycling) }\end{array}$ & 0.16 & 0.41 & 0.24 & 0.81 & 19.1 & 50.9 & 29.9 & 100.0 \\
\hline 23 & Construction & 0.00 & 1.14 & 0.00 & 1.14 & 0.0 & 100.0 & 0.0 & 100.0 \\
\hline 24 & Electricity, gas, water & 0.00 & 0.03 & 0.00 & 0.03 & 0.0 & 100.0 & 0.0 & 100.0 \\
\hline 25 & Wholesale and retail trades & 0.20 & 2.10 & 0.68 & 2.97 & 6.7 & 70.6 & 22.7 & 100.0 \\
\hline 26 & Financial services, real estate & 0.00 & 0.16 & 0.00 & 0.16 & 0.0 & 100.0 & 0.0 & 100.0 \\
\hline 27 & Transportation & 0.10 & 0.28 & 0.14 & 0.52 & 19.4 & 54.1 & 26.5 & 100.0 \\
\hline 28 & Services & 0.07 & 0.51 & 0.05 & 0.63 & 11.2 & 81.1 & 7.7 & 100.0 \\
\hline 29 & Public administration, public services & - & - & - & - & - & - & - & - \\
\hline \multirow[t]{2}{*}{30} & Unclassified & - & - & - & - & - & - & - & - \\
\hline & Total & 11.29 & 38.85 & 22.77 & 72.91 & 15.5 & 53.3 & 31.2 & 100.0 \\
\hline
\end{tabular}

Unit: Billion US dollars, \% 


\section{Contribution of Value-Added and Imports Against One-Unit Increase of Final Demand}

In this section, we discuss the contribution of value-added and imports against a oneunit increase in the final demand. It is well known that a one-unit increase in the final demand in one sector induces both direct and indirect products of each sector in the economies, and that the induced value-added and imports, if aggregated for all sectors of both countries, yields the same value as all initial increases in the final demand.

Table 5 shows the contribution of value-added and imports against a one-unit increase in the final demand in Japan. As expected, the value-added in Japan has the dominant share for almost all sectors. The exception is the "Petroleum and coal product" sector. Imports from the ROW are largely induced against an increase in the final demand in the "Petroleum and coal products" sector. "Chemical products," "Steel, non-steel metals, and metal products," "Household electronic equipment, and communications equipment," "Electronic computing equipment and accessories," and "Electricity, gas, water" sectors also induce higher import demands from the ROW. Imports from China, both Japanese subsidiaries and non-Japanese firms, are not induced as much as that from the ROW, because the import share from China is not dominant. However, examining each sector, there are several sectors that induce a relatively strong effect such as "Textiles, apparel and leather products," "Household electronic equipment, and communications equipment," "Industrial electric equipment," "Electronic computing equipment and accessories," "Motor vehicles," and "Precision instruments."

Table 6 shows the contribution of value-added and imports against a one-unit increase in the final demand in China-NJS. Value-added in China-NJS has the dominant share for almost all sectors with three exceptions, i.e., "Household electronic equipment, and communications equipment," "Electronic computing equipment and accessories," and "Precision instruments."

As China has greater energy resources, especially coal, the induced imports from the ROW are not as large in Japan in the "Petroleum and coal product" sector. On the other hand, imports from the ROW are largely induced against an increase in the final demand in several manufacturing sectors. The Japanese contribution is also large in the case of manufacturing; "Precision instruments," "Electronic computing equipment and accessories," "Household electronic equipment, and communications equipment," "Electronic components," "Motor vehicles," "Other transportation equipment," and "Plastic and rubber products." The major contribution of Japanese subsidiaries appears in the case of "Motor vehicles," and "Motor vehicle parts."

Table 7 shows the contribution of value-added and imports against a one-unit increase of the final demand in China-JS. Induced value-added in Japanese subsidiaries is dominant in limited cases, i.e., "Agriculture, forestry, husbandry," "Wholesale and retail trades," and "Financial services, real estate." However, if we consider the increased value-added of both Japanese subsidiaries and non-Japanese firms in China as a whole, the effects seem similar to those of the Chinese cases. Of course, there are distinguishing characteristics. First, the relation between Japan and its subsidiaries is relatively strong. The induced imports from Japan are large in the case of "Precision instruments," "Household electronic equipment, and communications equipment," "Electronic components," "Textiles, apparel and leather products," "Industrial 
Table 5 Contribution of value-added and import by sector, Japan

\begin{tabular}{|c|c|c|c|c|c|c|}
\hline & & Japan & China-NJS & China-JS & ROW & Total \\
\hline 1 & Agriculture, forestry, husbandry & 0.895 & 0.006 & 0.000 & 0.098 & 1.000 \\
\hline 2 & Fishery & 0.851 & 0.008 & 0.000 & 0.141 & 1.000 \\
\hline 3 & Mining & 0.846 & 0.005 & 0.000 & 0.149 & 1.000 \\
\hline 4 & Food & 0.829 & 0.012 & 0.000 & 0.159 & 1.000 \\
\hline 5 & Textiles, apparel, and leather products & 0.792 & 0.033 & 0.001 & 0.174 & 1.000 \\
\hline 6 & Lumber, wood products, paper and printing & 0.844 & 0.009 & 0.000 & 0.146 & 1.000 \\
\hline 7 & Chemical products & 0.713 & 0.016 & 0.001 & 0.270 & 1.000 \\
\hline 8 & Plastic and rubber products & 0.799 & 0.016 & 0.001 & 0.185 & 1.000 \\
\hline 9 & Petroleum and coal products & 0.343 & 0.003 & 0.000 & 0.653 & 1.000 \\
\hline 10 & Non-metal products & 0.866 & 0.011 & 0.001 & 0.123 & 1.000 \\
\hline 11 & Steel, non-steel metals, and metal products & 0.694 & 0.014 & 0.001 & 0.292 & 1.000 \\
\hline 12 & General machinery & 0.843 & 0.014 & 0.002 & 0.141 & 1.000 \\
\hline 13 & $\begin{array}{l}\text { Household electronic equipment, and } \\
\text { communications equipment }\end{array}$ & 0.737 & 0.022 & 0.013 & 0.227 & 1.000 \\
\hline 14 & $\begin{array}{l}\text { Household electric and non-electric } \\
\text { equipment }\end{array}$ & 0.819 & 0.014 & 0.003 & 0.165 & 1.000 \\
\hline 15 & Electronic components & 0.776 & 0.016 & 0.007 & 0.201 & 1.000 \\
\hline 16 & Industrial electric equipment & 0.782 & 0.028 & 0.003 & 0.187 & 1.000 \\
\hline 17 & $\begin{array}{l}\text { Electronic computing equipment and } \\
\text { accessories }\end{array}$ & 0.693 & 0.017 & 0.007 & 0.282 & 1.000 \\
\hline 18 & Motor vehicles & 0.829 & 0.017 & 0.004 & 0.149 & 1.000 \\
\hline 19 & Motor vehicle parts & 0.846 & 0.014 & 0.004 & 0.136 & 1.000 \\
\hline 20 & Other transportation equipment & 0.795 & 0.012 & 0.002 & 0.191 & 1.000 \\
\hline 21 & Precision instruments & 0.804 & 0.017 & 0.005 & 0.175 & 1.000 \\
\hline 22 & $\begin{array}{l}\text { Other miscellaneous manufacturing } \\
\text { (incl. reuse and recycling) }\end{array}$ & 0.863 & 0.014 & 0.001 & 0.122 & 1.000 \\
\hline 23 & Construction & 0.870 & 0.011 & 0.001 & 0.118 & 1.000 \\
\hline 24 & Electricity, gas, water & 0.720 & 0.005 & 0.000 & 0.275 & 1.000 \\
\hline 25 & Wholesale and retail trades & 0.948 & 0.002 & 0.000 & 0.050 & 1.000 \\
\hline 26 & Financial services, real estate & 0.975 & 0.001 & 0.000 & 0.024 & 1.000 \\
\hline 27 & Transportation & 0.834 & 0.003 & 0.000 & 0.163 & 1.000 \\
\hline 28 & Services & 0.931 & 0.004 & 0.000 & 0.064 & 1.000 \\
\hline 29 & Public administration, public services & 0.930 & 0.004 & 0.000 & 0.066 & 1.000 \\
\hline 30 & Unclassified & 0.920 & 0.004 & 0.000 & 0.076 & 1.000 \\
\hline
\end{tabular}

electric equipment," and "Electronic computing equipment and accessories" sectors, in which the FDI from Japan are large. If FDI and overseas productions are increased in the cases above, exports from Japan to China would increase. However, the output of the corresponding sectors in Japan might be reduced at the same time, if some independent final demand does not appear in the same sector. In such a case, the reduced output might offset the induced import, which we will discuss in the next section. 
Table 6 Contribution of value-added and import by sector, China except Japanese subsidiaries

\begin{tabular}{|c|c|c|c|c|c|c|}
\hline & & Japan & China-NJS & China-JS & ROW & Total \\
\hline 1 & Agriculture, forestry, husbandry & 0.004 & 0.940 & 0.001 & 0.055 & 1.000 \\
\hline 2 & Fishery & 0.004 & 0.941 & 0.001 & 0.054 & 1.000 \\
\hline 3 & Mining & 0.010 & 0.883 & 0.002 & 0.105 & 1.000 \\
\hline 4 & Food & 0.006 & 0.870 & 0.002 & 0.122 & 1.000 \\
\hline 5 & Textiles, apparel, and leather products & 0.017 & 0.800 & 0.002 & 0.181 & 1.000 \\
\hline 6 & Lumber, wood products, paper and printing & 0.016 & 0.786 & 0.003 & 0.195 & 1.000 \\
\hline 7 & Chemical products & 0.024 & 0.733 & 0.003 & 0.240 & 1.000 \\
\hline 8 & Plastic and rubber products & 0.033 & 0.670 & 0.003 & 0.294 & 1.000 \\
\hline 9 & Petroleum and coal products & 0.007 & 0.629 & 0.002 & 0.363 & 1.000 \\
\hline 10 & Non-metal products & 0.012 & 0.850 & 0.003 & 0.135 & 1.000 \\
\hline 11 & Steel, non-steel metals, and metal products & 0.014 & 0.741 & 0.003 & 0.242 & 1.000 \\
\hline 12 & General machinery & 0.028 & 0.752 & 0.003 & 0.216 & 1.000 \\
\hline 13 & $\begin{array}{l}\text { Household electronic equipment, and } \\
\text { communications equipment }\end{array}$ & 0.042 & 0.465 & 0.003 & 0.491 & 1.000 \\
\hline 14 & $\begin{array}{l}\text { Household electric and non-electric } \\
\text { equipment }\end{array}$ & 0.022 & 0.670 & 0.003 & 0.305 & 1.000 \\
\hline 15 & Electronic components & 0.035 & 0.585 & 0.003 & 0.376 & 1.000 \\
\hline 16 & Industrial electric equipment & 0.034 & 0.675 & 0.003 & 0.289 & 1.000 \\
\hline 17 & $\begin{array}{l}\text { Electronic computing equipment and } \\
\text { accessories }\end{array}$ & 0.051 & 0.356 & 0.002 & 0.591 & 1.000 \\
\hline 18 & Motor vehicles & 0.035 & 0.693 & 0.033 & 0.240 & 1.000 \\
\hline 19 & Motor vehicle parts & 0.022 & 0.742 & 0.021 & 0.215 & 1.000 \\
\hline 20 & Other transportation equipment & 0.034 & 0.715 & 0.003 & 0.248 & 1.000 \\
\hline 21 & Precision instruments & 0.060 & 0.471 & 0.003 & 0.467 & 1.000 \\
\hline 22 & $\begin{array}{l}\text { Other miscellaneous manufacturing } \\
\text { (incl. reuse and recycling) }\end{array}$ & 0.017 & 0.810 & 0.002 & 0.171 & 1.000 \\
\hline 23 & Construction & 0.013 & 0.833 & 0.003 & 0.151 & 1.000 \\
\hline 24 & Electricity, gas, water & 0.010 & 0.862 & 0.003 & 0.126 & 1.000 \\
\hline 25 & Wholesale and retail trades & 0.006 & 0.919 & 0.002 & 0.072 & 1.000 \\
\hline 26 & Financial services, real estate & 0.004 & 0.951 & 0.001 & 0.044 & 1.000 \\
\hline 27 & Transportation & 0.008 & 0.859 & 0.004 & 0.130 & 1.000 \\
\hline 28 & Services & 0.010 & 0.871 & 0.003 & 0.116 & 1.000 \\
\hline 29 & Public administration, public services & 0.008 & 0.904 & 0.003 & 0.085 & 1.000 \\
\hline 30 & Unclassified & - & - & - & - & - \\
\hline
\end{tabular}

\section{Simulation Analysis of a Production Shift to China}

\subsection{Motor Vehicles}

First, we consider the effect of a production shift in the "Motor vehicles" sector by comparing the reduction of value-added, which stems from a one-unit reduction in the final demand of this sector in Japan, to the increase of value-added, which is induced by a one-unit increase in the final demand in China-JS. 
Table 7 Contribution of value-added and import by sector, Japanese subsidiaries in China

\begin{tabular}{|c|c|c|c|c|c|c|}
\hline & & Japan & China-NJS & China-JS & ROW & Total \\
\hline 1 & Agriculture, forestry, husbandry & 0.003 & 0.177 & 0.790 & 0.030 & 1.000 \\
\hline 2 & Fishery & 0.045 & 0.602 & 0.253 & 0.100 & 1.000 \\
\hline 3 & Mining & 0.012 & 0.665 & 0.172 & 0.151 & 1.000 \\
\hline 4 & Food & 0.015 & 0.570 & 0.335 & 0.079 & 1.000 \\
\hline 5 & Textiles, apparel, and leather products & 0.189 & 0.336 & 0.280 & 0.195 & 1.000 \\
\hline 6 & Lumber, wood products, paper and printing & 0.063 & 0.281 & 0.398 & 0.258 & 1.000 \\
\hline 7 & Chemical products & 0.111 & 0.343 & 0.364 & 0.182 & 1.000 \\
\hline 8 & Plastic and rubber products & 0.094 & 0.316 & 0.379 & 0.210 & 1.000 \\
\hline 9 & Petroleum and coal products & 0.037 & 0.591 & 0.159 & 0.213 & 1.000 \\
\hline 10 & Non-metal products & 0.110 & 0.280 & 0.480 & 0.131 & 1.000 \\
\hline 11 & Steel, non-steel metals, and metal products & 0.133 & 0.441 & 0.215 & 0.211 & 1.000 \\
\hline 12 & General machinery & 0.129 & 0.361 & 0.268 & 0.242 & 1.000 \\
\hline 13 & $\begin{array}{l}\text { Household electronic equipment, and } \\
\text { communications equipment }\end{array}$ & 0.241 & 0.169 & 0.275 & 0.316 & 1.000 \\
\hline 14 & $\begin{array}{l}\text { Household electric and non-electric } \\
\text { equipment }\end{array}$ & 0.137 & 0.346 & 0.284 & 0.233 & 1.000 \\
\hline 15 & Electronic components & 0.226 & 0.210 & 0.266 & 0.298 & 1.000 \\
\hline 16 & Industrial electric equipment & 0.182 & 0.349 & 0.264 & 0.204 & 1.000 \\
\hline 17 & $\begin{array}{l}\text { Electronic computing equipment and } \\
\text { accessories }\end{array}$ & 0.173 & 0.115 & 0.270 & 0.442 & 1.000 \\
\hline 18 & Motor vehicles & 0.106 & 0.371 & 0.390 & 0.133 & 1.000 \\
\hline 19 & Motor vehicle parts & 0.099 & 0.274 & 0.499 & 0.127 & 1.000 \\
\hline 20 & Other transportation equipment & 0.120 & 0.414 & 0.302 & 0.164 & 1.000 \\
\hline 21 & Precision instruments & 0.275 & 0.204 & 0.318 & 0.203 & 1.000 \\
\hline 22 & $\begin{array}{l}\text { Other miscellaneous manufacturing } \\
\text { (incl. reuse and recycling) }\end{array}$ & 0.124 & 0.303 & 0.402 & 0.172 & 1.000 \\
\hline 23 & Construction & 0.014 & 0.571 & 0.280 & 0.135 & 1.000 \\
\hline 24 & Electricity, gas, water & 0.017 & 0.579 & 0.279 & 0.124 & 1.000 \\
\hline 25 & Wholesale and retail trades & 0.010 & 0.272 & 0.646 & 0.072 & 1.000 \\
\hline 26 & Financial services, real estate & 0.002 & 0.082 & 0.900 & 0.016 & 1.000 \\
\hline 27 & Transportation & 0.010 & 0.431 & 0.428 & 0.131 & 1.000 \\
\hline 28 & Services & 0.036 & 0.445 & 0.370 & 0.149 & 1.000 \\
\hline 29 & Public administration, public services & - & - & - & - & - \\
\hline 30 & Unclassified & - & - & - & - & - \\
\hline
\end{tabular}

The first four columns, named "(1) Japan," in Table 8 show the value-added of Japan, China-NJS, China-JS, and the import from the ROW, which are induced by a one-unit decrease of the final demand in "Motor vehicles," in Japan, according to Eq. (5) with a negative sign.

Abatement of the final demand of the "Motor vehicles" sector causes a diminishing demand in "Motor vehicle parts," "Steel, non-steel metals, and metal products," "Plastic and rubber products," and "Electronic components," as intermediate inputs. 
Table 8 Induced value-added and imports by one-unit shift of final products from Japan to Japanese subsidiaries in China, "Motor vehicles" sector

\begin{tabular}{|c|c|c|c|c|c|c|c|c|c|c|c|c|c|}
\hline & & \multicolumn{4}{|l|}{ (1) Japan } & \multicolumn{4}{|c|}{ (2) Japanese subsidiaries in China } & \multicolumn{4}{|c|}{ (3) Total effects } \\
\hline & & Japan & China-NJS & China-JS & ROW & Japan & China-NJS & China-JS & ROW & Japan & China-NJS & China-JS & ROW \\
\hline 1 & Agriculture, forestry, husbandry & -0.001 & -0.001 & 0.000 & -0.002 & 0.000 & 0.011 & 0.000 & 0.003 & -0.001 & 0.011 & 0.000 & 0.001 \\
\hline 2 & Fishery & 0.000 & 0.000 & 0.000 & 0.000 & 0.000 & 0.001 & 0.000 & 0.000 & 0.000 & 0.001 & 0.000 & 0.000 \\
\hline 3 & Mining & -0.001 & -0.002 & 0.000 & -0.033 & 0.000 & 0.028 & 0.000 & 0.029 & -0.001 & 0.026 & 0.000 & -0.004 \\
\hline 4 & Food & -0.003 & 0.000 & 0.000 & -0.001 & 0.000 & 0.005 & 0.000 & 0.001 & -0.002 & 0.004 & 0.000 & 0.000 \\
\hline 5 & Textiles, apparel, and leather products & -0.002 & 0.000 & 0.000 & -0.001 & 0.001 & 0.006 & 0.000 & 0.001 & -0.001 & 0.006 & 0.000 & 0.001 \\
\hline 6 & Lumber, wood products, paper and printing & -0.009 & 0.000 & 0.000 & -0.001 & 0.003 & 0.010 & 0.000 & 0.002 & -0.007 & 0.009 & 0.000 & 0.001 \\
\hline 7 & Chemical products & -0.014 & -0.001 & 0.000 & -0.011 & 0.003 & 0.015 & 0.001 & 0.014 & -0.011 & 0.014 & 0.000 & 0.003 \\
\hline 8 & Plastic and rubber products & -0.031 & -0.001 & 0.000 & -0.006 & 0.004 & 0.010 & 0.001 & 0.003 & -0.027 & 0.010 & 0.001 & -0.003 \\
\hline 9 & Petroleum and coal products & -0.007 & 0.000 & 0.000 & -0.005 & 0.001 & 0.007 & 0.000 & 0.003 & -0.006 & 0.006 & 0.000 & -0.002 \\
\hline 10 & Non-metal products & -0.010 & 0.000 & 0.000 & -0.001 & 0.001 & 0.005 & 0.000 & 0.000 & -0.009 & 0.005 & 0.000 & 0.000 \\
\hline 11 & Steel, non-steel metals, and metal products & -0.040 & -0.002 & 0.000 & -0.018 & 0.008 & 0.044 & 0.003 & 0.013 & -0.032 & 0.042 & 0.003 & -0.005 \\
\hline 12 & General machinery & -0.019 & -0.001 & 0.000 & -0.002 & 0.006 & 0.030 & 0.004 & 0.008 & -0.013 & 0.030 & 0.004 & 0.006 \\
\hline 13 & $\begin{array}{l}\text { Household electronic equipment, and } \\
\text { communications equipment }\end{array}$ & -0.003 & 0.000 & 0.000 & -0.002 & 0.000 & 0.000 & 0.000 & 0.001 & -0.003 & 0.000 & 0.000 & -0.001 \\
\hline 14 & $\begin{array}{l}\text { Household electric and non-electric } \\
\text { equipment }\end{array}$ & 0.000 & 0.000 & 0.000 & 0.000 & 0.000 & 0.002 & 0.000 & 0.000 & 0.000 & 0.002 & 0.000 & 0.000 \\
\hline 15 & Electronic components & -0.008 & 0.000 & 0.000 & -0.009 & 0.002 & 0.001 & 0.000 & 0.008 & -0.006 & 0.001 & 0.000 & -0.001 \\
\hline
\end{tabular}


Table 8 (Continued)

\begin{tabular}{|c|c|c|c|c|c|c|c|c|c|c|c|c|c|}
\hline & & \multicolumn{4}{|l|}{ (1) Japan } & \multicolumn{4}{|c|}{ (2) Japanese subsidiaries in China } & \multicolumn{4}{|c|}{ (3) Total effects } \\
\hline & & Japan & China-NJS & China-JS & ROW & Japan & China-NJS & China-JS & ROW & Japan & China-NJS & China-JS & ROW \\
\hline 16 & Industrial electric equipment & -0.021 & -0.001 & 0.000 & -0.009 & 0.003 & 0.005 & 0.001 & 0.005 & -0.019 & 0.004 & 0.000 & -0.004 \\
\hline 17 & $\begin{array}{l}\text { Electronic computing equipment and } \\
\text { accessories }\end{array}$ & 0.000 & 0.000 & 0.000 & 0.000 & 0.000 & 0.000 & 0.000 & 0.000 & 0.000 & 0.000 & 0.000 & 0.000 \\
\hline 18 & Motor vehicles & -0.229 & 0.000 & 0.000 & -0.010 & 0.003 & 0.013 & 0.335 & 0.001 & -0.226 & 0.013 & 0.334 & -0.009 \\
\hline 19 & Motor vehicle parts & -0.171 & 0.000 & -0.002 & -0.012 & 0.029 & 0.040 & 0.040 & 0.007 & -0.141 & 0.039 & 0.037 & -0.005 \\
\hline 20 & Other transportation equipment & 0.000 & 0.000 & 0.000 & 0.000 & 0.000 & 0.001 & 0.000 & 0.000 & 0.000 & 0.001 & 0.000 & 0.000 \\
\hline 21 & Precision instruments & -0.001 & 0.000 & 0.000 & 0.000 & 0.003 & 0.001 & 0.000 & 0.006 & 0.002 & 0.001 & 0.000 & 0.005 \\
\hline 22 & $\begin{array}{l}\text { Other miscellaneous manufacturing } \\
\text { (incl. reuse and recycling) }\end{array}$ & -0.005 & -0.001 & 0.000 & -0.002 & 0.001 & 0.006 & 0.000 & 0.004 & -0.004 & 0.005 & 0.000 & 0.002 \\
\hline 23 & Construction & -0.004 & 0.000 & 0.000 & 0.000 & 0.001 & 0.000 & 0.000 & 0.000 & -0.004 & 0.000 & 0.000 & 0.000 \\
\hline 24 & Electricity, gas, water & -0.017 & -0.001 & 0.000 & 0.000 & 0.002 & 0.021 & 0.000 & 0.000 & -0.015 & 0.020 & 0.000 & 0.000 \\
\hline 25 & Wholesale and retail trades & -0.068 & -0.001 & 0.000 & -0.001 & 0.012 & 0.031 & 0.002 & 0.000 & -0.055 & 0.029 & 0.002 & -0.001 \\
\hline 26 & Financial services, real estate & -0.042 & -0.001 & 0.000 & 0.000 & 0.006 & 0.022 & 0.000 & 0.000 & -0.037 & 0.021 & 0.000 & 0.000 \\
\hline 27 & Transportation & -0.024 & -0.001 & 0.000 & -0.003 & 0.004 & 0.021 & 0.002 & 0.001 & -0.020 & 0.020 & 0.002 & -0.002 \\
\hline 28 & Services & -0.095 & -0.001 & 0.000 & -0.008 & 0.012 & 0.033 & 0.001 & 0.007 & -0.082 & 0.032 & 0.001 & -0.001 \\
\hline 29 & Public administration, public services & -0.004 & 0.000 & 0.000 & 0.000 & 0.001 & 0.001 & 0.000 & 0.000 & -0.003 & 0.001 & 0.000 & 0.000 \\
\hline 30 & Unclassified & -0.002 & 0.000 & 0.000 & -0.001 & 0.000 & 0.000 & 0.000 & 0.000 & -0.002 & 0.000 & 0.000 & -0.001 \\
\hline
\end{tabular}


Reduction of inputs of "Wholesale and retail trades," "Financial services, real estate," "Services," and "Transportation" are also relatively large in Japanese Motor vehicle production. However, the change of inputs from China, including Japanese subsidiaries, is relatively small. Among imported intermediate inputs, the relatively large effects are observed in "Mining," "Steel, non-steel metals, and metal products," "Chemical products," "Electronic components," and "Industrial electric equipment."

Next, the four columns, named "(2) China-JS," in Table 8 show the induced valueadded and imports, caused by a one-unit increase of the final demand in the "Motor vehicles" sector in China-JS, which is computed by Eq. (7). Intermediate inputs in this sector are large in "Motor vehicles" and "Motor vehicle parts" sectors. The values in these two inputs differ relatively little between Japan and China. However, their total sum yields almost the same values, and the patterns of the other inputs are also similar. Inputs of "Motor vehicle parts" are purchased from Japan and within the Chinese market, and inputs of "Steel, non-steel metals, and metal products" are also purchased within the Chinese market. There are enormous coal reserves in China, so the share of domestic supplies in this sector is great compared to Japan.

The final four columns, named "(3) Total effects," in Table 8 show the effect of the production shift of the "Motor vehicles" sector from Japan to China, computed by Eq. (9). Naturally, a one-unit reduction of final demand in Japan's "Motor vehicles" sector has negative impacts on Japan, especially on the "Motor vehicles" and "Motor vehicle parts" sectors. On the other hand, the increase in "Motor vehicles" final demands in a Japanese subsidiary has positive impacts on those sectors in China-JS. Increased outputs of Motor vehicles in China positively affect production in Japan through its intermediate import inputs. However, negative impacts on Japanese production offset such positive effects because of the decrease in the final demand of Japan. $^{11}$

\subsection{Household Electric and Non-electric Equipment}

A similar simulation is applied to the "Household electric and non-electric equipment" sector, which includes Table 9.

In the first four columns named (1) in Table 9, we are able to observe the impacts on value-added by sectors, brought about by a one-unit decrease in a final demand in the "Household electric and non-electric equipment" sector in Japan. The valueadded of this sector suffers the largest negative impacts. "Steel, non-steel metals, and metal products," and "Electronic components" then follow.

The next four columns named (2) in Table 9 cause similar impacts due to a oneunit increase in the final demand in the same sector in China-JS. In this case, the

\footnotetext{
${ }^{11}$ In the 1980's, the exports of motor vehicles from Japan to the US vastly increased, and the share of Japanese motor vehicles in the US market became much larger. At that time, Japanese automobile companies assumed voluntary control of exports, and shifted to local production in the US. However, the exports of "Motor vehicles" from Japan to China were not as much as those from Japan to the US. Thus, the purpose of overseas production is mainly a new expansion into the China market for motor vehicles. So there is no evidence that the export of motor vehicles is directly affected by this expansion. Here our simulation shows the opportunity cost in the sense of how much "Motor vehicles" in Japan might lose potential production for export to China, if the overseas production would not start up in China.
} 
Table 9 Induced value-added and imports by one-unit shift of final products from Japan to Japanese subsidiaries in China, "Household electric and non-electric equipment" sector

\begin{tabular}{|c|c|c|c|c|c|c|c|c|c|c|c|c|c|}
\hline & & \multicolumn{4}{|l|}{ (1) Japan } & \multicolumn{4}{|c|}{ (2) Japanese subsidiaries in China } & \multicolumn{4}{|c|}{ (3) Total effects } \\
\hline & & Japan & China-NJS & China-JS & ROW & Japan & China-NJS & China-JS & ROW & Japan & China-NJS & China-JS & ROW \\
\hline 1 & Agriculture, forestry, husbandry & -0.002 & -0.001 & 0.000 & -0.002 & 0.000 & 0.014 & 0.000 & 0.004 & -0.001 & 0.013 & 0.000 & 0.002 \\
\hline 2 & Fishery & 0.000 & 0.000 & 0.000 & 0.000 & 0.000 & 0.001 & 0.000 & 0.000 & 0.000 & 0.001 & 0.000 & 0.000 \\
\hline 3 & Mining & -0.001 & -0.002 & 0.000 & -0.042 & 0.000 & 0.032 & 0.000 & 0.037 & 0.000 & 0.031 & 0.000 & -0.005 \\
\hline 4 & Food & -0.003 & 0.000 & 0.000 & -0.001 & 0.001 & 0.005 & 0.000 & 0.001 & -0.002 & 0.005 & 0.000 & 0.000 \\
\hline 5 & Textiles, apparel, and leather products & -0.003 & 0.000 & 0.000 & -0.001 & 0.001 & 0.005 & 0.000 & 0.001 & -0.002 & 0.005 & 0.000 & 0.000 \\
\hline 6 & Lumber, wood products, paper and printing & -0.020 & 0.000 & 0.000 & -0.002 & 0.002 & 0.009 & 0.002 & 0.003 & -0.018 & 0.009 & 0.002 & 0.000 \\
\hline 7 & Chemical products & -0.013 & -0.001 & 0.000 & -0.008 & 0.006 & 0.022 & 0.003 & 0.028 & -0.007 & 0.021 & 0.003 & 0.019 \\
\hline 8 & Plastic and rubber products & -0.028 & 0.000 & 0.000 & -0.003 & 0.006 & 0.020 & 0.005 & 0.007 & -0.021 & 0.020 & 0.005 & 0.004 \\
\hline 9 & Petroleum and coal products & -0.007 & 0.000 & 0.000 & -0.005 & 0.002 & 0.008 & 0.000 & 0.005 & -0.006 & 0.007 & 0.000 & 0.000 \\
\hline 10 & Non-metal products & -0.006 & 0.000 & 0.000 & -0.001 & 0.003 & 0.006 & 0.001 & 0.002 & -0.003 & 0.006 & 0.001 & 0.001 \\
\hline 11 & Steel, non-steel metals, and metal products & -0.072 & -0.002 & 0.000 & -0.025 & 0.014 & 0.050 & 0.006 & 0.025 & -0.058 & 0.047 & 0.006 & 0.000 \\
\hline 12 & General machinery & -0.015 & 0.000 & 0.000 & -0.001 & 0.009 & 0.014 & 0.003 & 0.013 & -0.006 & 0.013 & 0.003 & 0.012 \\
\hline 13 & $\begin{array}{l}\text { Household electronic equipment, and } \\
\text { communications equipment }\end{array}$ & 0.000 & 0.000 & 0.000 & 0.000 & 0.000 & 0.000 & 0.000 & 0.000 & 0.000 & 0.000 & 0.000 & 0.000 \\
\hline 14 & $\begin{array}{l}\text { Household electric and non-electric } \\
\text { equipment }\end{array}$ & -0.329 & 0.000 & 0.000 & -0.008 & 0.004 & 0.005 & 0.236 & 0.007 & -0.325 & 0.005 & 0.235 & -0.001 \\
\hline 15 & Electronic components & -0.039 & 0.000 & -0.002 & -0.034 & 0.020 & 0.002 & 0.003 & 0.045 & -0.020 & 0.002 & 0.002 & 0.011 \\
\hline
\end{tabular}


Table 9 (Continued)

\begin{tabular}{|c|c|c|c|c|c|c|c|c|c|c|c|c|c|}
\hline & & \multicolumn{4}{|c|}{ (1) Japan } & \multicolumn{4}{|c|}{ (2) Japanese subsidiaries in China } & \multicolumn{4}{|c|}{ (3) Total effects } \\
\hline & & Japan & China-NJS & China-JS & ROW & Japan & China-NJS & China-JS & ROW & Japan & China-NJS & China-JS & ROW \\
\hline 16 & Industrial electric equipment & -0.012 & -0.001 & 0.000 & -0.006 & 0.011 & 0.010 & 0.006 & 0.019 & -0.002 & 0.009 & 0.006 & 0.013 \\
\hline 17 & $\begin{array}{l}\text { Electronic computing equipment and } \\
\text { accessories }\end{array}$ & 0.000 & 0.000 & 0.000 & 0.000 & 0.000 & 0.001 & 0.000 & 0.001 & 0.000 & 0.001 & 0.000 & 0.001 \\
\hline 18 & Motor vehicles & 0.000 & 0.000 & 0.000 & 0.000 & 0.000 & 0.000 & 0.000 & 0.000 & 0.000 & 0.000 & 0.000 & 0.000 \\
\hline 19 & Motor vehicle parts & 0.000 & 0.000 & 0.000 & 0.000 & 0.000 & 0.002 & 0.001 & 0.000 & 0.000 & 0.002 & 0.001 & 0.000 \\
\hline 20 & Other transportation equipment & 0.000 & 0.000 & 0.000 & 0.000 & 0.000 & 0.001 & 0.000 & 0.000 & 0.000 & 0.001 & 0.000 & 0.000 \\
\hline 21 & Precision instruments & 0.000 & 0.000 & 0.000 & 0.000 & 0.002 & 0.000 & 0.000 & 0.007 & 0.002 & 0.000 & 0.000 & 0.007 \\
\hline 22 & $\begin{array}{l}\text { Other miscellaneous manufacturing } \\
\text { (incl. reuse and recycling) }\end{array}$ & -0.005 & 0.000 & 0.000 & -0.003 & 0.002 & 0.008 & 0.001 & 0.005 & -0.004 & 0.008 & 0.001 & 0.002 \\
\hline 23 & Construction & -0.004 & 0.000 & 0.000 & 0.000 & 0.001 & 0.000 & 0.000 & 0.000 & -0.004 & 0.000 & 0.000 & 0.000 \\
\hline 24 & Electricity, gas, water & -0.016 & -0.001 & 0.000 & 0.000 & 0.003 & 0.022 & 0.000 & 0.000 & -0.013 & 0.021 & 0.000 & 0.000 \\
\hline 25 & Wholesale and retail trades & -0.069 & -0.001 & 0.000 & -0.001 & 0.017 & 0.024 & 0.003 & 0.000 & -0.052 & 0.023 & 0.003 & -0.001 \\
\hline 26 & Financial services, real estate & -0.048 & -0.001 & 0.000 & 0.000 & 0.008 & 0.030 & 0.000 & 0.000 & -0.040 & 0.029 & 0.000 & 0.000 \\
\hline 27 & Transportation & -0.020 & -0.001 & 0.000 & -0.003 & 0.006 & 0.020 & 0.006 & 0.002 & -0.014 & 0.019 & 0.006 & -0.001 \\
\hline 28 & Services & -0.098 & -0.001 & 0.000 & -0.006 & 0.018 & 0.034 & 0.005 & 0.016 & -0.080 & 0.033 & 0.005 & 0.010 \\
\hline 29 & Public administration, public services & -0.004 & 0.000 & 0.000 & 0.000 & 0.001 & 0.001 & 0.000 & 0.000 & -0.003 & 0.001 & 0.000 & 0.000 \\
\hline 30 & Unclassified & -0.003 & 0.000 & 0.000 & -0.001 & 0.001 & 0.000 & 0.000 & 0.000 & -0.003 & 0.000 & 0.000 & -0.001 \\
\hline
\end{tabular}


value-added of "Electronic components" sector receives the largest impact in Japan. The final four columns named (3) in Table 9 show the effect of a production shift from Japan to China. In this case, Japanese value-added decrease mainly in the "Household electric and non-electric equipment" sector, which cannot be offset by the increasing effects brought by the shift of production in China-JS.

\subsection{Household Electronic Equipment, and Communications Equipment}

Here, we discuss the effects of the production shift in the "Household electronic equipment, and communications equipment" sector. The first four columns named (1) in Table 10 show the impacts on the value-added by sector, caused by the change in the Japanese final demand. The value-added in "Household electronic equipment, and communications equipment," and "Electronic components" has a great impact. Especially, in the "Electronic components" sector, the import from the ROW shows almost the same value as that from Japan, and the input from China-JS is small in both cases.

The next four columns named (2) in Table 10 show the effects of China-JS. Similarly, a major increase in the value-added appears in the "Household electric and non-electric equipment" and "Electronic components" sector. As for the "Electronic components" sector, we recognize significant effects in Japan and the ROW.

The last four columns named (3) in Table 10 show the effects of the production shift, in which the "Household electronic equipment, and communications equipment" sector is mainly affected in its value-added. However, a production shift shows no effect on the value-added in the "Electronic components" sector. This means that the main features of the production in the "Household electric and non-electric equipment" sector are readily supplied from both Japan and the ROW actually in Chinese Taipei or Korea, which is a very interesting result.

\subsection{Production Shift in Manufacturing Sectors}

So far we have discussed the effects of production shifts for three main sectors, in terms of the changes in value-added and imports by sector and regions. The aggregation by sectors reports the effects on Japan, China-NJS, China-JS, and the ROW. The first four columns in Table 11 show the regional impacts on the value-added and imports brought about by the production shift from Japan to China in each sector. ${ }^{12}$

Observing this figure for the cases of "Household electric and non-electric equipment," "Electronic components," "Electronic computing equipment and accessories," and "Industrial electric equipment," the Japanese decrease in value-added is relatively small, though a relatively large decrease appears in the case of "Motor vehicles" and "Motor vehicle parts."

Table 11, in the last three columns, contains also the impact on the compensation of employees for the production shift in each manufacturing sector. For almost all

\footnotetext{
${ }^{12}$ Because the total change of final demands is zero for each sector, the sum of the induced value-added and induced imports will also be zero, when the induced change of international freight and insurance are included.
} 
Table 10 Induced value-added and imports by one-unit shift of final products from Japan to Japanese subsidiaries in China, "Household electronic equipment, and communications equipment" sector

\begin{tabular}{|c|c|c|c|c|c|c|c|c|c|c|c|c|c|}
\hline & & \multicolumn{4}{|l|}{ (1) Japan } & \multicolumn{4}{|c|}{ (2) Japanese subsidiaries in China } & \multicolumn{4}{|c|}{ (3) Total effects } \\
\hline & & Japan & China-NJS & China-JS & ROW & Japan & China-NJS & China-JS & ROW & Japan & China-NJS & China-JS & ROW \\
\hline 1 & Agriculture, forestry, husbandry & -0.002 & -0.001 & 0.000 & -0.002 & 0.000 & 0.007 & 0.000 & 0.002 & -0.001 & 0.006 & 0.000 & 0.000 \\
\hline 2 & Fishery & 0.000 & 0.000 & 0.000 & 0.000 & 0.000 & 0.001 & 0.000 & 0.000 & 0.000 & 0.001 & 0.000 & 0.000 \\
\hline 3 & Mining & 0.000 & -0.002 & 0.000 & -0.024 & 0.000 & 0.013 & 0.000 & 0.020 & 0.000 & 0.011 & 0.000 & -0.004 \\
\hline 4 & Food & -0.003 & 0.000 & 0.000 & -0.001 & 0.001 & 0.003 & 0.000 & 0.001 & -0.002 & 0.003 & 0.000 & -0.001 \\
\hline 5 & Textiles, apparel, and leather products & -0.002 & 0.000 & 0.000 & 0.000 & 0.001 & 0.002 & 0.000 & 0.001 & -0.001 & 0.002 & 0.000 & 0.000 \\
\hline 6 & Lumber, wood products, paper and printing & -0.016 & -0.001 & 0.000 & -0.002 & 0.004 & 0.005 & 0.001 & 0.002 & -0.012 & 0.004 & 0.001 & 0.000 \\
\hline 7 & Chemical products & -0.013 & -0.001 & 0.000 & -0.009 & 0.005 & 0.009 & 0.001 & 0.013 & -0.007 & 0.008 & 0.001 & 0.004 \\
\hline 8 & Plastic and rubber products & -0.030 & -0.001 & 0.000 & -0.003 & 0.006 & 0.009 & 0.002 & 0.004 & -0.024 & 0.008 & 0.002 & 0.001 \\
\hline 9 & Petroleum and coal products & -0.005 & 0.000 & 0.000 & -0.004 & 0.002 & 0.003 & 0.000 & 0.003 & -0.003 & 0.003 & 0.000 & -0.001 \\
\hline 10 & Non-metal products & -0.006 & -0.001 & 0.000 & -0.001 & 0.005 & 0.003 & 0.001 & 0.001 & -0.001 & 0.002 & 0.000 & 0.001 \\
\hline 11 & Steel, non-steel metals, and metal products & -0.023 & -0.003 & 0.000 & -0.013 & 0.010 & 0.018 & 0.002 & 0.015 & -0.013 & 0.015 & 0.001 & 0.001 \\
\hline 12 & General machinery & -0.006 & -0.001 & 0.000 & -0.001 & 0.004 & 0.007 & 0.002 & 0.004 & -0.002 & 0.007 & 0.002 & 0.003 \\
\hline 13 & $\begin{array}{l}\text { Household electronic equipment, and } \\
\text { communications equipment }\end{array}$ & -0.243 & 0.000 & -0.001 & -0.007 & 0.010 & 0.001 & 0.238 & 0.064 & -0.233 & 0.001 & 0.237 & 0.057 \\
\hline 14 & $\begin{array}{l}\text { Household electric and non-electric } \\
\text { equipment }\end{array}$ & 0.000 & 0.000 & 0.000 & 0.000 & 0.000 & 0.000 & 0.000 & 0.000 & 0.000 & 0.000 & 0.000 & 0.000 \\
\hline 15 & Electronic components & -0.102 & -0.001 & -0.010 & -0.120 & 0.088 & 0.004 & 0.014 & 0.136 & -0.014 & 0.004 & 0.004 & 0.015 \\
\hline
\end{tabular}


Table 10 (Continued)

\begin{tabular}{|c|c|c|c|c|c|c|c|c|c|c|c|c|c|}
\hline & & \multicolumn{4}{|l|}{ (1) Japan } & \multicolumn{4}{|c|}{ (2) Japanese subsidiaries in China } & \multicolumn{4}{|c|}{ (3) Total effects } \\
\hline & & Japan & China-NJS & China-JS & ROW & Japan & China-NJS & China-JS & ROW & Japan & China-NJS & China-JS & ROW \\
\hline 16 & Industrial electric equipment & -0.016 & -0.001 & 0.000 & -0.008 & 0.011 & 0.004 & 0.002 & 0.014 & -0.005 & 0.003 & 0.002 & 0.006 \\
\hline 17 & $\begin{array}{l}\text { Electronic computing equipment and } \\
\text { accessories }\end{array}$ & 0.000 & 0.000 & 0.000 & 0.000 & 0.000 & 0.001 & 0.000 & 0.001 & 0.000 & 0.001 & 0.000 & 0.001 \\
\hline 18 & Motor vehicles & 0.000 & 0.000 & 0.000 & 0.000 & 0.000 & 0.000 & 0.000 & 0.000 & 0.000 & 0.000 & 0.000 & 0.000 \\
\hline 19 & Motor vehicle parts & 0.000 & 0.000 & 0.000 & 0.000 & 0.000 & 0.001 & 0.001 & 0.000 & 0.000 & 0.001 & 0.001 & 0.000 \\
\hline 20 & Other transportation equipment & 0.000 & 0.000 & 0.000 & 0.000 & 0.000 & 0.001 & 0.000 & 0.000 & 0.000 & 0.000 & 0.000 & 0.000 \\
\hline 21 & Precision instruments & -0.002 & 0.000 & 0.000 & -0.001 & 0.004 & 0.000 & 0.000 & 0.012 & 0.002 & 0.000 & 0.000 & 0.012 \\
\hline 22 & $\begin{array}{l}\text { Other miscellaneous manufacturing } \\
\text { (incl. reuse and recycling) }\end{array}$ & -0.003 & -0.001 & 0.000 & -0.001 & 0.001 & 0.004 & 0.001 & 0.002 & -0.002 & 0.003 & 0.001 & 0.001 \\
\hline 23 & Construction & -0.005 & 0.000 & 0.000 & 0.000 & 0.002 & 0.000 & 0.000 & 0.000 & -0.003 & 0.000 & 0.000 & 0.000 \\
\hline 24 & Electricity, gas, water & -0.014 & -0.002 & 0.000 & 0.000 & 0.005 & 0.010 & 0.000 & 0.000 & -0.008 & 0.008 & 0.000 & 0.000 \\
\hline 25 & Wholesale and retail trades & -0.062 & -0.002 & 0.000 & -0.001 & 0.026 & 0.016 & 0.003 & 0.000 & -0.036 & 0.014 & 0.003 & -0.001 \\
\hline 26 & Financial services, real estate & -0.042 & -0.002 & 0.000 & 0.000 & 0.013 & 0.020 & 0.000 & 0.000 & -0.029 & 0.019 & 0.000 & 0.000 \\
\hline 27 & Transportation & -0.018 & -0.001 & 0.000 & -0.003 & 0.008 & 0.009 & 0.003 & 0.002 & -0.010 & 0.008 & 0.003 & -0.001 \\
\hline 28 & Services & -0.117 & -0.002 & 0.000 & -0.008 & 0.031 & 0.019 & 0.002 & 0.012 & -0.086 & 0.017 & 0.002 & 0.004 \\
\hline 29 & Public administration, public services & -0.004 & 0.000 & 0.000 & 0.000 & 0.001 & 0.000 & 0.000 & 0.000 & -0.003 & 0.000 & 0.000 & 0.000 \\
\hline 30 & Unclassified & -0.002 & 0.000 & 0.000 & -0.001 & 0.001 & 0.000 & 0.000 & 0.000 & -0.002 & 0.000 & 0.000 & 0.000 \\
\hline
\end{tabular}


Table 11 Comparison of total induced valued-added, imports, and compensation of employees by production shift of each manufacturing sector

\begin{tabular}{|c|c|c|c|c|c|c|c|c|}
\hline & & \multicolumn{4}{|c|}{ Value-added and imports } & \multicolumn{3}{|c|}{ Compensation of employees } \\
\hline & & Japan & China-NJS & China-JS & ROW & Japan & China-NJS & China-JS \\
\hline 4 & Food & -0.813 & 0.558 & 0.335 & -0.072 & -0.315 & 0.380 & 0.069 \\
\hline 5 & Textiles, apparel, and leather products & -0.603 & 0.303 & 0.279 & 0.031 & -0.378 & 0.149 & 0.061 \\
\hline 6 & Lumber, wood products, paper and printing & -0.780 & 0.272 & 0.397 & 0.118 & -0.415 & 0.114 & 0.083 \\
\hline 7 & Chemical products & -0.602 & 0.327 & 0.363 & -0.077 & -0.296 & 0.131 & 0.053 \\
\hline 8 & Plastic and rubber products & -0.705 & 0.301 & 0.379 & 0.029 & -0.406 & 0.107 & 0.149 \\
\hline 9 & Petroleum and coal products & -0.306 & 0.587 & 0.159 & -0.388 & -0.025 & 0.194 & 0.037 \\
\hline 10 & Non-metal products & -0.756 & 0.269 & 0.479 & 0.014 & -0.394 & 0.089 & 0.048 \\
\hline 11 & Steel, non-steel metals, and metal products & -0.561 & 0.428 & 0.214 & -0.069 & -0.292 & 0.138 & 0.035 \\
\hline 12 & General machinery & -0.714 & 0.347 & 0.266 & 0.104 & -0.419 & 0.113 & 0.035 \\
\hline 13 & $\begin{array}{l}\text { Household electronic equipment, and } \\
\text { communications equipment }\end{array}$ & -0.497 & 0.146 & 0.262 & 0.097 & -0.292 & 0.049 & 0.042 \\
\hline 14 & $\begin{array}{l}\text { Household electric and non-electric } \\
\text { equipment }\end{array}$ & -0.682 & 0.333 & 0.281 & 0.073 & -0.375 & 0.112 & 0.051 \\
\hline 15 & Electronic components & -0.550 & 0.193 & 0.260 & 0.103 & -0.308 & 0.064 & 0.062 \\
\hline 16 & Industrial electric equipment & -0.600 & 0.322 & 0.261 & 0.023 & -0.363 & 0.104 & 0.047 \\
\hline 17 & $\begin{array}{l}\text { Electronic computing equipment and } \\
\text { accessories }\end{array}$ & -0.520 & 0.098 & 0.263 & 0.172 & -0.301 & 0.031 & 0.043 \\
\hline 18 & Motor vehicles & -0.723 & 0.354 & 0.386 & -0.020 & -0.439 & 0.125 & 0.019 \\
\hline 19 & Motor vehicle parts & -0.747 & 0.260 & 0.495 & -0.007 & -0.476 & 0.088 & 0.034 \\
\hline 20 & Other transportation equipment & -0.675 & 0.402 & 0.300 & -0.022 & -0.421 & 0.136 & 0.057 \\
\hline 21 & Precision instruments & -0.528 & 0.187 & 0.313 & 0.032 & -0.337 & 0.063 & 0.060 \\
\hline 22 & $\begin{array}{l}\text { Other miscellaneous manufacturing } \\
\text { (incl. reuse and recycling) }\end{array}$ & -0.739 & 0.289 & 0.400 & 0.054 & -0.306 & 0.139 & 0.099 \\
\hline
\end{tabular}


sectors except "Petroleum and coal products," the decrease in the Japanese compensation of employees is significant in value compared to the Chinese increase in the compensation. This means that production shifts to China make room to cover that cost. Actually, in comparing each sector, "Motor vehicles" and "Motor vehicle parts" sectors have a major reduction effect on saving labor costs. However, how much effect this has on employment should be investigated by an analysis using employment coefficient data in both countries, as a topic of our future research.

\section{Concluding Remarks}

The production shift of firms from one country to another changes the pattern of trade between them. There is an increasing concern that such changes in the international trade structure between Japan and China might lead to the demise of the manufacturing industry. On the other hand, it is widely recognized that FDI plays an important role in Chinese economic development. Input-Output Analysis is one of the important tools used to investigate such issues.

For the purpose stated above, by using information of the METI overseas business survey database, we tried to reconstruct the 2007 Japan-China International InputOutput Table so as to include the production activities of Japanese subsidiaries in China as explicit sectors. The reconstructed table captures how Japanese firms contribute to Chinese economic development by supplying final goods to the Chinese domestic market, exporting to overseas markets, and supplying intermediate goods to support the production of firms in China.

The continuous appreciation of the Yen and the rapid aging of the Japanese population have forced Japanese firms to shrink domestic production and to enlarge overseas production, by reducing production costs and seeking new markets. According to our simulation of the production shift from Japan to China, which is induced from pairwise assumptions, a one-unit decrease of final goods in Japan and a one-unit increase of final goods produced by Japanese subsidiaries in China, we are able to observe the following: (1) A reduction in Japanese value-added occurs in almost all sectors in Japan, but dominantly in the corresponding sector. (2) An increase of value-added, through which the production shift is induced from Japan to Japanese subsidiaries in China, is smaller than the reduction of value-added in Japan. (3) A change in the compensation of employees is also similar to that of value-added, which suggests that the production shift might be related to the cost reduction. (4) Worldwide suppliers that distribute some key intermediate goods, like "Electronic components" against "Household electronic equipment, and communication equipment," might not suffer so much from such a production shift.

The effect on employment brought about by a production shift is also an import issue, which we should plan to investigate after developing the employment table. It is important to capture the characteristics of an input structure for Japanese overseas production. Should the cost structure resemble a Japanese or a Chinese one? Though the value-added ratio to total input in the manufacturing sector shows the technology in China-JS is similar to the Japanese one, a more detailed analysis is required.

From where and for how much should they purchase intermediate goods; Japan, China, or the ROW? A METI “overseas business survey” is important to supply such 
detailed information. We must expansions and improvements in such survey statistics. The merchandise trade data in Chinese Customs might be important to improve our study. Finally, because the economic development of China includes regional inequality, we have to investigate production shifts, using a Japan-China transnational interregional input-output table, like IDE (2007).

\section{Competing Interests}

The author declares that he has no competing interests.

Acknowledgements This paper was originally presented at the 20th International Input-Output Conference, held in Bratislava, from 24th to 29th June 2012. We used some microdata of the METI Overseas Business Survey Database on China for 2006 and 2007 for our study. We express our gratitude for permission to use the database. We also appreciate the anonymous referees for their valuable comments and suggestions. This study is financially supported by a Grant-in-Aid for Scientific Research (C) of JSPS, Japan (No. 22530212).

\section{References}

Albino V, Dietzenbacher E, Kühtz S (2003) Analysing materials and energy flows in an industrial district using an enterprise input-output model. Econ Syst Res 15(4):457-480

Institute of Developing Economies (2007) Transnational interregional input-output table between China and Japan 2000. Asian international input-output series, vol 68

Institute of Development Economics (2013) Asian International Input-Output Table 2005. Statistical data series, vol 98

Koopman R, Wang Z, Wei S (2012) Estimating domestic content in exports when processing trade is pervasive. J Dev Econ 99:178-189

Marangoni G, Colombo G, Fezzi G (2004) Modelling intra-group relationships. Econ Syst Res 16(1):85104

Matsumoto M, Fujimoto J (2008) The development of an enterprise input output model and its application to industrial environment management. J Appl Input-Output Anal 13 \& 14:123-143

METI, Research and Statistics Department, Economic and Industry Policy Bureau (2005) Analysis of Japanese overseas firms using recompiled 2000 Japan-US International Input Output Table. In: 2000 Japan-US International Input Output Table, analysis part, pp 28-53 (in Japanese)

Teng J, Fang W (2008) An input-output analysis of the economic dependence between Japanese enterprise and non-Japanese enterprise in China and Japan. J Appl Input-Output Anal 13 \& 14:33-60

Timmer MP (ed) (2012) The World Input-Output Database (WIOD): contents, sources and methods. Working paper 10, WIOD Consortium

Working Party of the Trade Committee, OECD (2012) Mapping global value chains. http://www.oecd.org/ dac/aft/MappingGlobalValueChains_web_usb.pdf

Yamada M (2002) Overseas production of Japanese firms and Japan-US interdependence: an input-output analysis. J Appl Input-Output Anal 8:15-36

Yamada M (2004) Japanese overseas production within the Asia international input-output framework: Japan, the US, and Asia. J Econom Study Northeast Asia 5(1):27-42. (In: Kinoshita S (ed) (2012) Econometric modeling of Japan and Asia-Pacific economies. World Scientific, Singapore, Chapter 4)

Yang C, Chen X, Duan Y, Jiang X, Pei J, Xu J, Yang L, Zhu K (2012) Measurement of trade in value-added: using Chinese input-output tables capturing processing trade. http://www.statistics.gov.hk/wsc/ STS024-P3-S.pdf 